\title{
المرأة الكوردية الإيزيدية في الانعكاسات القانونية والفقهية لعمليات الإبادة في جرائم داعش
}

(دراسة تاريخية مقارنة)

\author{
رمزية هزة حسن الدوسكي \\ قسم التربية الدينية، كلية العلوم الانسانية، جامعة دهوك، اقليم كوردستان-العراق
}

(تاريخ القبول بالنشر: 30 كانون الثاني، 2019)

الخلاصة

سعى البحث الى مناقشة إشكالية تدور حول ماهية الأنظمة والقرارات الدولية والمعايير المتفق عليها لحماية حقوق الإنسان في مختلف الجنتمعات،والدور الفعال للأمم المتحدة في تغيير السلوكيات الشاذة من خلال وضعها للائحة حقوق الإنسان، ونلقي الضوء على المبادئ الاخلاقية للفقه الاسلامي في تعامله مع الجانب الانساني، فمن المعلوم الذي يهمنا هنا هي مكانة المرأة، ومن هذه الاشكالية أشتقت فرضيات الإنسات البحث من الجانب التطبيقي في حياة المرأة الكوردية الإيزيدية في الإنعكاسات القانونية والفقهية لعمليات الإبادة،وأختتم البحث بنتائج عدة منها

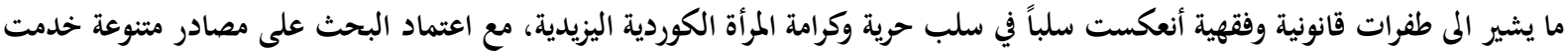

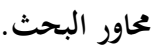

الكلمات المفتاحية: المرأة، القوانين الدولية، الإبادة، حقوق الإنسان، الإسلام.

من جهة اخرى، فضلاً عن العزوف من قبل بعض

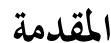

من النساء والجهات المعنية في تقديم المعلومات الدقيقة التي تخدم البحث ولأسبابٍ جمة،حاولنا قدر الإمكان اجتياز هذه الصعوبة وعدم الخروج من إطار موضوع المرأة الإيزيدية من المواضيع المهمة التي شغلت فكر الكثير من المؤرخين والباحثين والمهتمين المنهج التاريخي حيث صميم الاختصاص، قسم بقايا حقوق الإنسان في العالم، ولكن من القلة أن البحث فضلاً عن الحلاصة والمقدمة الى ثلاثة نجد من اهتم بشأن إجراء دراسة مقارنة ميدانية وفق مباحث الاول تناول ((حقوق المرأة في القوانين معايير علمية بين ضحايا الفكر الداعشي، والوصول الدولية)) حيث سرد فيها بعض من القوانين والسنن الى بعض من الحقائق المجدية، لذلك وقع الاختيار الدولية التي تخص موضوع البحث، اما المبحث الثاني على هذا الموضوع، وانصب الجهد قدر الإمكان الذي خصص للحديث عن (( الحقوق الإنسانية

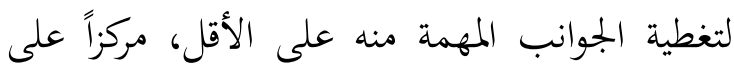
للمرأة غير المسلمة في الفقه الإسلامي)) فيه إشارات

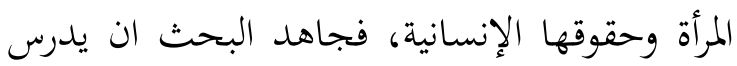
الى بعض من الآيات القرآنية والأحاديث النبوية

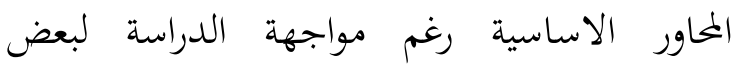
التي تخص حقوق الانسان... والمبحث الثالث الصعوبات منها عامل الزمن، وندرة المعلومات أحياناً 
ووضع أسس وصياغات تطيح بالتشوهات حول دور

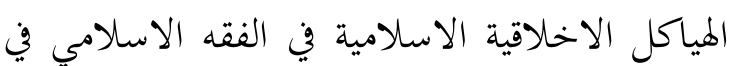

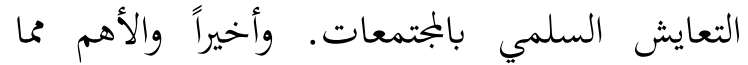
سبق، القيام بالتدوين التاريخي لعمليات الإبادة التي

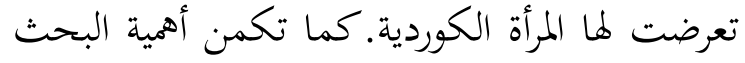
بالربط بين التاريخ الحديث والمعاصر والإسلامي بتوظيف نصوصها لخدمة المستقبل. منهج البحسث: من اجل تحقيق اهداف البحث

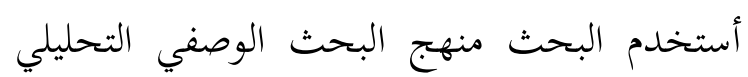
لتمحيص النصوص المستخدمة، وتوظيفها لخدمة

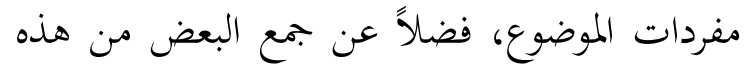

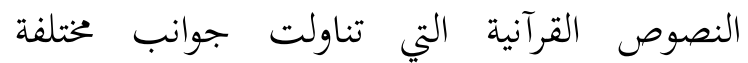
للبحث، والرجوع الى التفاسير التي شرحت وفسرت التئي هذه النصوص بصيغة علمية. واستنتاج رأي الاسلام

$$
\text { في تساؤلات البحث. }
$$

\section{المبحث الأول: حقوق المرأة في القوانين الدولية:}

أولاً: مقدمة في حقوق الإنسان (1):

لم تكن الحقوق والحريات التي حصل عليها الإنسان وليدة زمنية معينة أو مكان واحد، إذ أن تطور الحقوق والحريات عملية تمت في أماكن عديدة

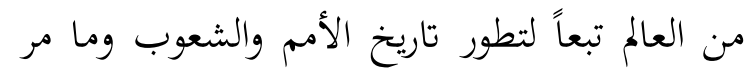
عليها من احداث سياسية وأقتصادية واجتماعية. فالإنسان هو محور الحدث لهذه الحقوق جميعاً

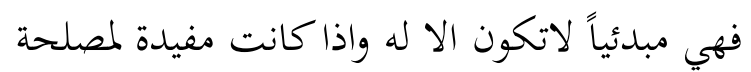

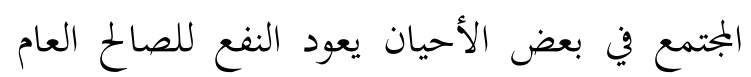

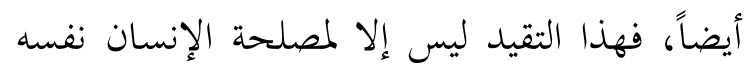

الموسوم بـ (( إستشهادات ميدانية لانتهاك حقوق المرأة الكوردية الإيزيدية)) كرس هذا الفصل للبحث

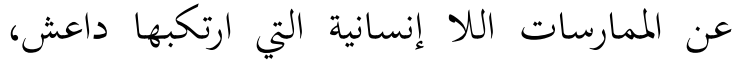
وذلك من خلال لقاءات شخصية حيث تعتبر مصادر حية تعالج مشكلة البحث.

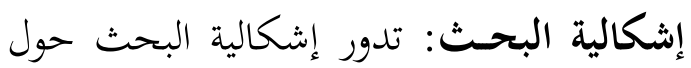

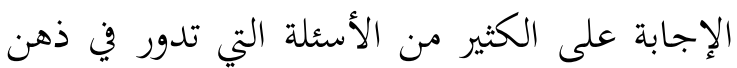

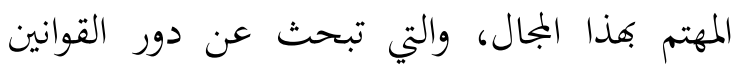
والمعايير العالمية لحماية حقوق الإنسان، وفي الاسلام كديانة أعتنقها بجرمو الحرب كتنظيم داعش. ويمكن العماني تفكيك هذه الاشكالية بشكل مختصر كالآتي:- ما القوانين التي تخص بحقوق الانسان في منظمة التحاليدان

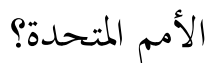
- ما الآيات القرآنية التي تخص حرية الإنسان في

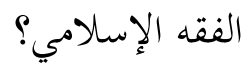
- ما الآيات القرآنية التي تخص حرية التدين في

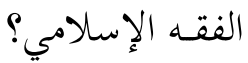

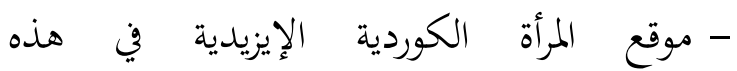
الانعكاسات. وغيرها من الإشكاليات. - فرضيات البحث: هل المرأة إنسان وحقوقها مصانة في المواثيق الدولية؟ هل المرأة إنسان في الفقه الفهان الإسلامي؟ وما حقوقها التي تضمن لما المستقبل؟

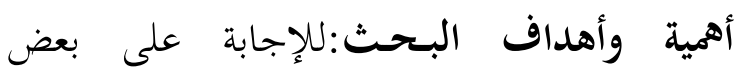
التساؤلات التي تثبت أن حقوق الإنسان في المواثيق

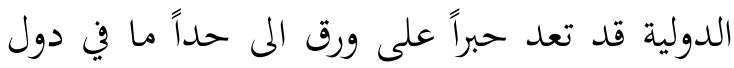
العالم الثالث، فضلاً عن تغير بعض المفاهيم الخاطئة حول حقوق المرأة في الإسلام كإنسانة بغض النظر

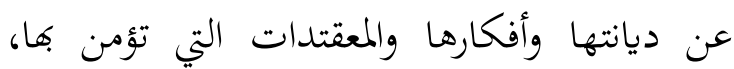


ثانياً: الخلفية التاريخية لنشوء فكرة حقوق الإنسان: - الان

شهد تطور حقوق الإنسان وإنماء المجتمع الإنساني عدة مراحل كمرحلة العادات والتقاليد ومرحلة القانون، ومن ثم مرحلة الدستور وانتهاءً بالمرحلة الدولية (7). ففي القديم كان المجتمع يتكون من عدة أسر، كانية فإن اية منها كانت ذات قوة اوامرها كانت سارية بين الناس (أي كانت عوضاً عن القانون المحلي)،

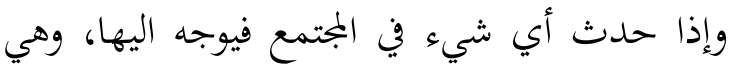

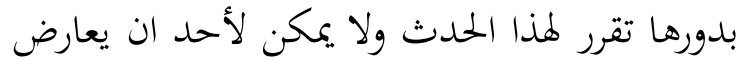
قرارها، عرف بينهم برئيس القبيلة (8) هذا الأمر أدى الى نشوء النظام الطبقي في المجتمعات البشرية، ووفق شريحتين اساسيتين وهما

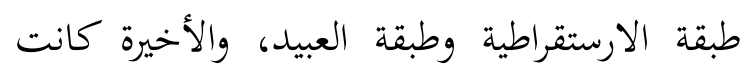

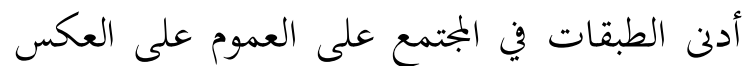

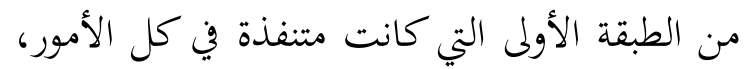

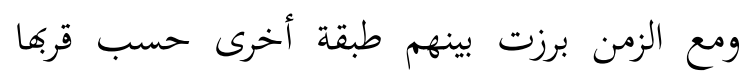
وبعدها من السلطة، عرفت بالطبقة الوسطى (9).

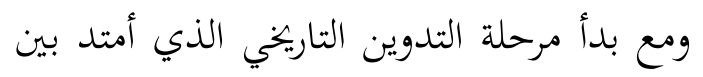

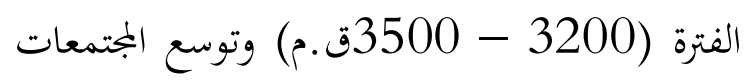

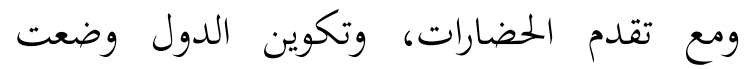
القوانين من قبل الدولة وعرفت بالقوانين المدونة، وإن

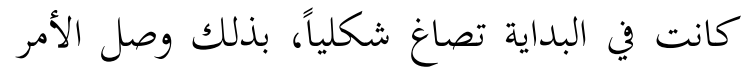
إلى تقيد الناس وفق الأحكام، (10) كقوانين حمورابي (11)، وقوانين صولون (12)، وقوانين الاثنتي عشرة لوحة الرومانية (13)
الذي هو مدني بطبعه ولابد له من التعايش الاجتماعي مع أخيه الإنسان (2). ويرى أرسطو أن الإنسان بطبعه كائن أجتماعي، الإنسان

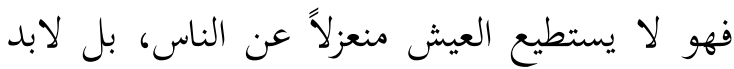

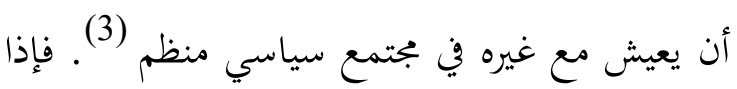
وجد شخص يعيش بحكم طبيعته لا بحكم المصادفة

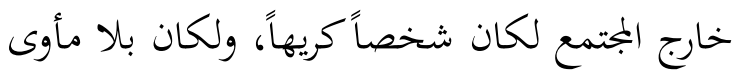

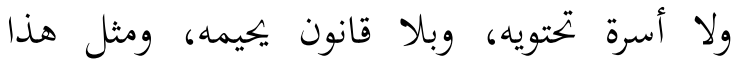
الشخص لا يفكر سوى بالحرب دون أي تقيد

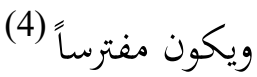
هذا يجب أن تخضع إرادة الأفراد الى القانون،

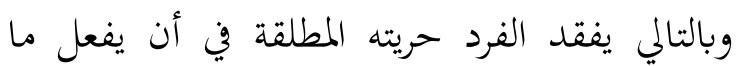
يشاء، بل ينبغي أن تكون أفعاله منسجمه مع لعالهال القانون الذي يضمن العدالة والمساواة للجميع (5). إذاً حقوق الإنسان جزء من الحقوق الطبيعية والتي هي حقوق لصيقة بشخصية الإنسان ولا يمكن أن إن الإنسي

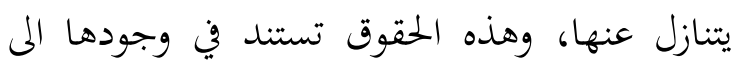
القانون الطبيعي والذي هو المثل الأعلى الذي يراد تحقيقه (6) هذا لا يككن القول بوجود لحظة محددة بدأت

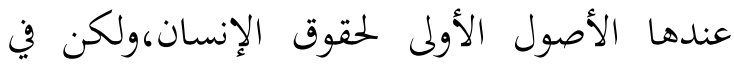
غالب الظن أن هذه الأصول بدأت مع تكوين الإنسات

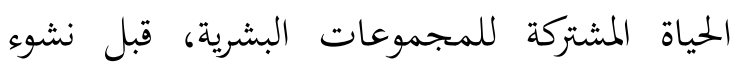

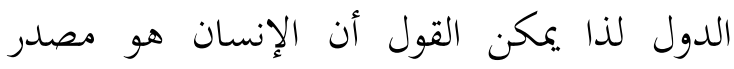

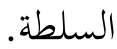


كان لإعلان حقوق الإنسان والمواطنة في فرنسا من خلال سبعة عشر بنداً ، والتي أدرجت تلك لإِك البنود سنة 1791 في الدستور الفرنسي، وجاء ذلك إثر اندلاع الثورة الفرنسية سنة1789 في الثنود (22) والذي وجاء ذلكيك اسس على أثرها مجلس الشعب (البرلمان) مستفيداً من النموذج البريطاني والامريكي لحقوق الإنسان

الإنسان هو محور كل الحقوق، هو والحقوق لا ينفصلان، ولكن بالرغم من وجود هذه العلاقة الوثيقة؛ فإن هناك حقوقا رئيسية للإنسان لا يمكن لإن الاستغناء عنها، كما وفي الوقت ذاته توجد للإنسان حقوق ثانوية يمكن الاستغناء عنها لأها تضره، لذلك ضمنت البنود الدستورية الكثير من المعاهدات

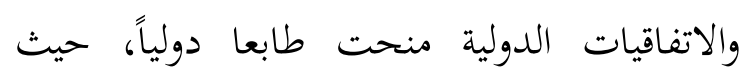
عقدت الكثير من الاجتماعات بين الدول،ب عضها كان لحل مشاكلهم وبعضها الاخر لتثبيت دعائم القانون الدولي والتوقيع على المعاهدات الخاصة بحقوق الإنسان (24). ثالثاً: الأمم المتحدة (25) وحقوق الإنسان: جاءت الأمم المتحدة لتحل محل عصبة الامم التي أنحلت سنة1945 لعدم نجاحها في تثبيت دعائم السلام اعقاب الحرب العالمية الثانية - 1945 ـوكان لها هدفان اساسيان هما: 1. السلام، حيث ينبغي ان يبني على اساس التساوي بين الشعوب وحق تقرير مصيرها (26).

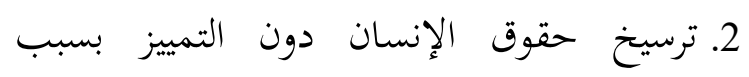
العرق، اللغة، الدين، او التركيب الاثني (27).
ومن أجل تنظيم اكثر للعلاقة الماثلة بين المرء والمجتمع تطور القانون ليولد الدستور الذي هو عبارة عن مجموعة من المبادئ العامة التي تحدد نوعية النظام في الدولة، كما تحدد خصوصية سلطة كل من سن سن السلطات الثلاث(التشريعية - التنفيذية - - القضائية) واستقلالية كل منها عن الأخرى، ومن ثم تحدد الحريات الشخصية وحقوقها وواجباتها والتي تعتبر مصدر القوانين في الدولة (14). كانت التجربة البريطانية هي السابقة في هذا المجال، وذلك عندما فرض شعبها معاهدة ماكناكارتا سنة1215م على رئيسهم للتوقيع على صك يتضمن عدداً من مبادئ حقوق إنسان لذلك

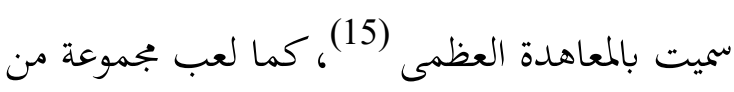
العلماء والمثقفين والفنانين دوراً بارزاً في تأجيج الشعوب بالمطالبة بحقوهم المشروعة في عصر النهضة

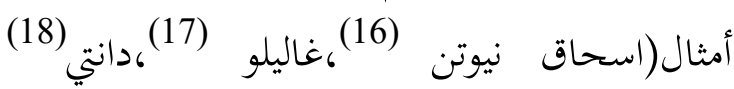
كوبر نيكوس (19) وغيرهم)، مهر هؤلاء دوراً في خلق أرضية خصبة لإنماء وتثبيت حقوق الإنسان. إن إعلان الاستقلال الأمريكي لأول مرة في سنة1776م (20) سُلمت السلطة الى فلسفة الضوء حيث أكد هذا القانون على أن الأفراد ولدوا سواسية، وأن الخالق قد منحهم حقوقاً ثابتة، ومن الن الترادئ هذا المنطلق غيرت ثلاث عشرة ولاية من الولايات المتحدة الامريكية دستورها الأساسي، وأضافت ثماني ولايات اخرى في مناطق نفوذها ذلك الاعلان لحقوق الإنسان على دستورها كلها تحرص على الحقوق الشخصية (21) 
تناولت الاتفاقية الأولى الحقوق المدنية والسياسية في 53بنداً، موقعة عليها124دولة من الدول الدال الأعضاء والتي أعلنت عن التزامها بالاتفاقية، هذه الاتفاقية تدعو الدول الأعضاء الى وضع الإجراءات المالائمة التي تؤمن الحماية للأقليات الشعبية والدينية والعرقية التي تعيش ضمن حدود دولهم (33). واما بخصوص الاتفاقية الثانية التي كانت تتعلق مواضعها الحقوق الاقتصادية والاجتماعية والثقافية، والتي كانت تتكون من ديباجة و 31 بنداً تتحدث عن(حق العمل، والمستوى المعيشي الجيد، العدالة في

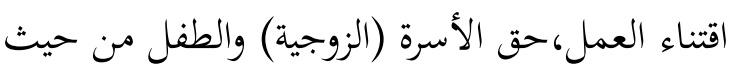
الحماية والتربية والتعليم......الخ) (34). ان موضوع حقوق الإنسان في العصر الحديث

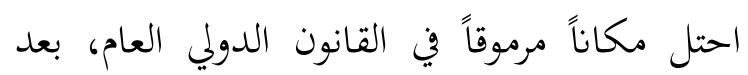
عشرين عاماً على صدور الاعلان العالمي، انعقد الحوار مجدداً في الأمم المتحدة وخارجها لتفعيل الاحترام العالمي لحقوق الإنسان فانعقد مؤتمر طهران في سنة 1968م كخطوة هامة لتعزيز حقوق الإنسان (35).

ويف السبعينيات حدث تطور مهم بخصوص موضوع حقوق الإنسان، حيث جرى تقديمه كمبدأ ملزم من مبادئ القانون الدولي بموجب وثيقة مؤتمر

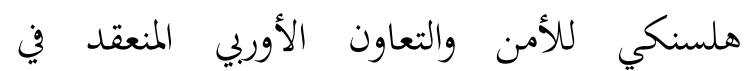
1975/8/1م (36)، وفي اتفاقية برلين الموقعة في حزيران من سنة 1991م أكدت على أحقية الدول الأعضاء التدخل في الحد من انتهاكات حقوق الإنسان، والتي سميت فيما بعد بعمبدأ التدخل الإنساني (37). وفي اعقاب التطورات السياسية التي
مع البرامج والمهام المتعددة للأمم المتحدة لا يهمنا إلا ما يتعلق بموضوعنا، وهو إعلانها العالمي

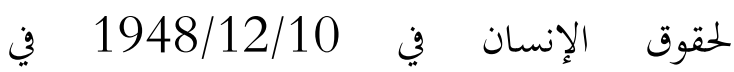
30بنداً،متظمنة حقوق متعددة منها(حق الحياة، الحرية، السلامة، الشخصية، المساواة امام القانون، اجتناب الاعتقال العفوي، المحاكمة العلنية، حرية التنقل، حق الالتجاء الى دولة ما، حق الجنسية، الزوجية، التملك، حق التعبير عن الرأي، المشاركة في

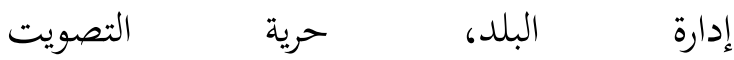
والانتخاب........الخ) (28). وفي سنة 1949 اتفقت الدول الاعضاء في الأمم المتحدة بجنيف على أربع نقاط مهمة، وهي حماية جرحى الحروب، الاسرى، الاماكن المقدسة، والاماكن الدينية، جاءت هذه الاتفاقية بعد تعديل اتفاقية لاهاي التي ابرمت سنة 1899م في مدينة لاهاي (29)، التي تتعلق بحماية حقوق الإنسان في الحروب وحماية الاسرى والجرحى (30). ولم تبق هذه على حالها بل تم تعديل نص الاتفاقية في سنة 1907، فأولوا اهتماماً خاصاً بجرحى الحرب والأسرى والاشخاص المدنيين (31). بعد ذلك بسنوات عدة وماب ين سنة 1955 1966م ناقشت الدول الأعضاء في الأمم المتحدة بجدية تامة متبادلة الآراء فيما بينهم حول الحقوق المدنية والسياسية والثقافية والاجتماعية، حتى تمكنت في الوصول الى إعلان اتفاقيتين مختلفتين فضلاً عن

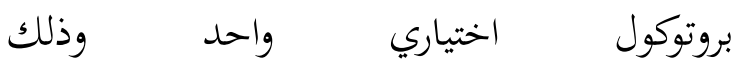
بتاريخ 1966/12/16م (32) 
بالكرامة والحقوق ويتميزون بعقول وضمائر وواجبهم التعامل مع البعض بروح الأخوة)( (40) وتعددت البنود حول الحق في الحرية الإنسانية في ممارسة ما يشاء وفق قوانين الدولة التي ينتمي إليها، بغض النظر عن الدين والفكر والمعتقد والانتماء، فضلاً عن الحق في ممارسة الحياة والحرية والأمان الشخصي، وورد ذلك جلياً في البنود(2 ،3وغيرها) حيث ورد في البند الثاني:(( كل فرد يتمتع بكافة الحقوق والحريات المنصوص عنها في هذا الإعلان بدون تمييز من أي نوع مثل العرق (41) واللون

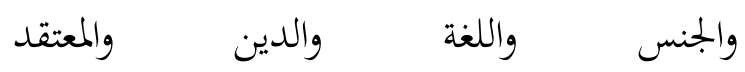

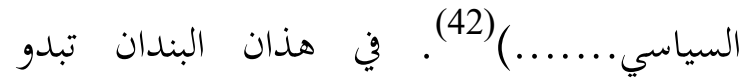
الصورة واضحة عن حقوق النساء إسوةً بالرجال في المجتمعات البشرية، لأنه ما ورد في النصين يشملهما دون تميز. جاء البند الثالث ليؤكد ما جاء في البند الأول، بخصوص هبة الله في خلق البشر أحرار وحق

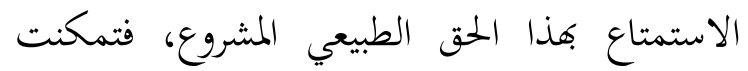
الأمم المتحدة من الوقوق على هذا الأمر بتحريم

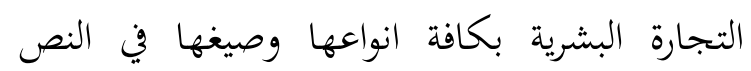
الذي قيل فيه:(( يحرم الاقتناء والتجارة بالعبيد

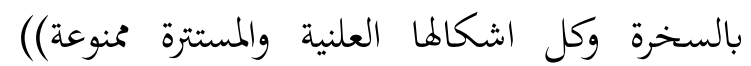

الاعتقالات والتعرض للتعذيب والإقامة الجبرية من الأمور التي أولتها اهمية خاصة هذا الإعلان، في البند الخامس جاء هذا القول واضحاً:(( تمنع ممارسة التعذيب ولا يجوز تعريض الفرد لعقوبات أو معاملة قاسية او وحشية من قبل أي جهة ولأي سبب
مر بها العالم انعقد مؤتمر آخر في فينا لحقوق الأنسان بتاريخ 1992/6/4م (38). وجاء في اعلان أخر للأمم المتحدة لحقوق الإنسان والذي أبرم عقده بمدينة فينا في الفترة مابين14 - 25 من حزيران سنة 1993، وأهم ما لإنسان ورد في نصه: ((أن حقوق الإنسان جميعاً وحدة

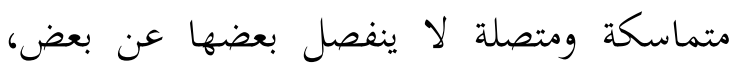
فعلى المجتمع الدولي ان يعمل معاً.......الخ)(39). بعد هذا العرض المختصر المكثف عن دور الأمم المتحدة في بث السلام في العالم بصورة عامة، علينا الوقوف على لب اهتمامه ألا وهو مكانة المرأة في هذا الاتفاقيات، وما حصلت عليها من حقوق، وما عليها من الالتزامات إن وجدت.

رابعاً: حقوق المرأة الإنسانة في القوانين الدولية: أتسعت قائمة الحقوق والحريات الواردة في

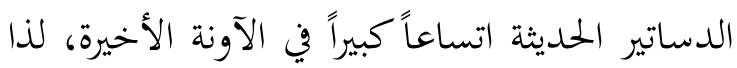
قبل الشروع بموضوع حقوق المرأة في القوانين الدولية، وعلى رأسها الإعلان العالمي لحقوق الإنسان من قبل الأمم المتحدة، لابد من الوقوف هنا على بعض إلى البنود التي تخص حقوق الإنسان، التي تشمل المرأة أيضاً بكوها إنسان. أولاً: المرأة في بنود حقوق الإنسان: بما أن لائحة حقوق الإنسان التي أعلنت في 1948/12/10 كانت تضمنت 30 بنداً و وفي له مقدمتها حق الحرية الشخصية للإنسان جاء في البند الأول القائل:(( كل البشر يولدون احراراً متساوين 
أما في الملحقين الإضافيين الى اتفاقيات جنيف سنة 1949 كان هناك فصل خاص بالمرأة تحت عنوان إجراءات لصالح النساء والأطفال، فئ لئل المادة76 الخاصة بحماية النساء في 3 نقاط رئيسية جاء فيها:(( يجب أن تكون النساء موضع احترام

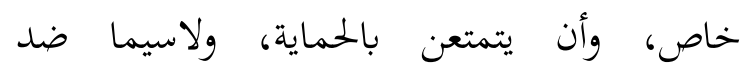
الاغتصاب والاكراه على الدعارة، وضد أي صورة من صور خدش الحياء، وتعطى الاولوية القصوى للنظر في قضايا أولات الأحمال وأمهات الأطفال الاولية الفهري

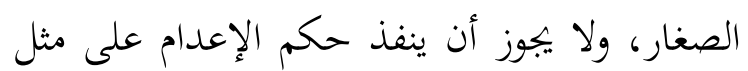

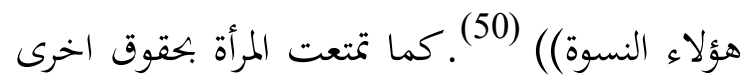

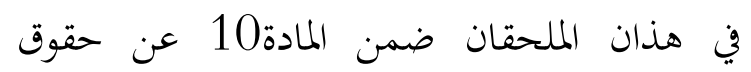
المدنيين، فهو لب المجتمع المدني (51). بسبب تزايد معدل الاتحار بالنساء والفتيات في البلدان النامية، اولت الجمعية العامة للأمم المتحدة

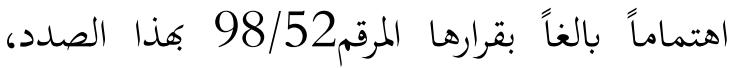
تشير الى قمع الاتحار بالأشخاص واستغلال بغاء

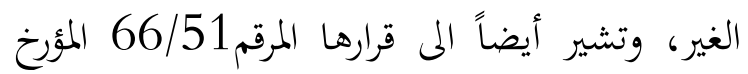

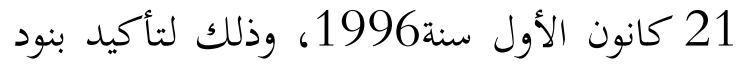
المؤتمر العالمي لحقوق الإنسان المعقود في فيينا 14 - 14 25 حزيران سنة 1993 (52). الجمعية العامة للأمم المتحدة تتعهد بكفالة كهيئة

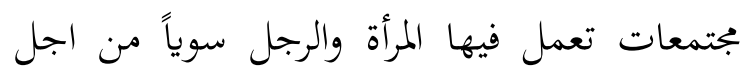
إيجاد عالم يمكن فيه لكل فرد أن يتمتع بالمساواة والتنمية والسلام)، ففي الجلسة العامة (بناء على تقرير اللجنة المخصصة الجامعة للدورة الاستثنئية الثالثة

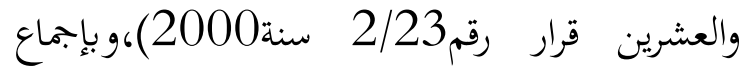
الحكومات المشاركة في الدورة الاستنائية العامة
كان)) (44). وماثل هذا القول البند التاسع عن:(( )

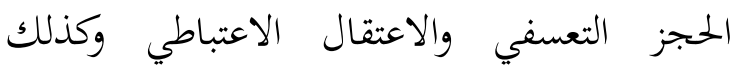
النفي)(الحجز (45)

سادت بنود الإعلان هذا مواضيع متعددة تخص حرية وكرامة الأنسان باختلاف الجنسين، ومن بين ذلك حفظ كرامة الأسرة، ذكر هذا في البند الثاني عشر:(( لا يجوز التدخل في خصوصيات الفرد وعائلته ولا منزله ولا مراسلاته ولا اتصالاته ولا يجوز

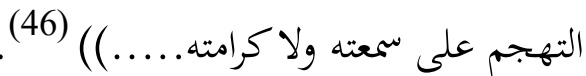

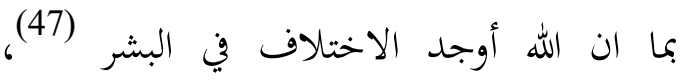
ستكون هنالك حتمية التنوع في الأفكار والضمائر

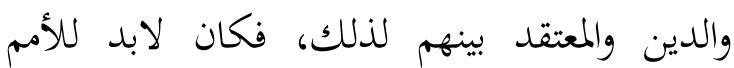
المتحدة ان تدرجها ضمن بنود الاعلان هذا، حيث خصص البند الثامن عشر لهذا الجانب فقد ورد فيه:(( لكل فرد الحق في ممارسة حرية التفكر والضمير والدين وكذلك كل الحرية في تغيير دينه

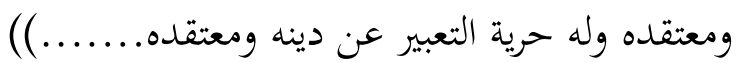

ثانياً: البنود الخاصة بالمرأة في لوائح حقوق

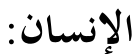

انشأت الجمعية العامة للأمم المتحدة لجنة مركز

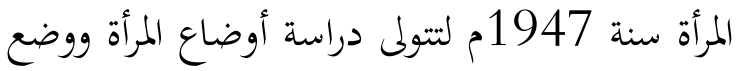
التوصيات التي تساعد في رسم سياسات النهوض بها على المستوى العالمي باعتبار أن التمييز ضد المرأة يمثل خرقاً لمبدأ المساواة في الحقوق واحترام الكرامة الانسانية المنصوص عليهما في الاعلان العالمي لمقوق الانسان (49). 
البروتوكول هو أن يعيد للأذهان، ان العهدين

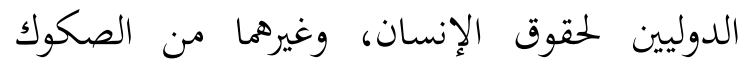

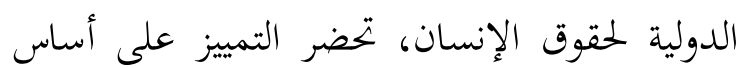

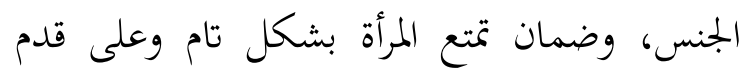

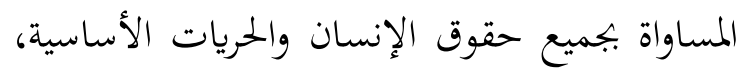

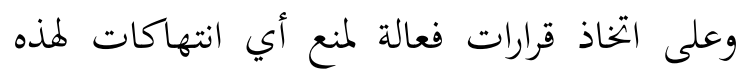

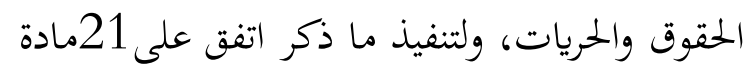
تضمن للمرأة حقوقها المشروعة (59). كان لقرار 52/ 100 سنة 1996 من قبرة لمبل الجمعية العامة للأمم المتحدة بشأن متابعة المؤتمر

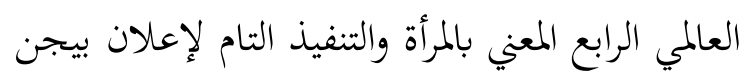

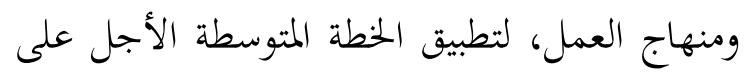

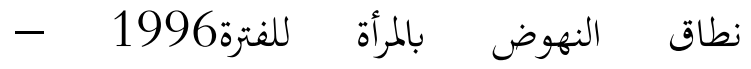

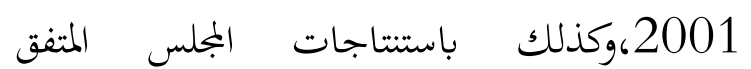
عليهاسنة1997 بشأن إدماج المنظور المتعلق بنوع الجنس في جميع سياسات منظومة الأمم المتحدة وبرابجها، إذ تؤكد على الإجراءات الفورية والمتضافرة لإقامة عالم يسوده السلام في 48 فقرة رئيسية فضلاً فقرات فرعية أخرى (60). ولم تقف اعمال الجمعية العامة للأمم المتحدة

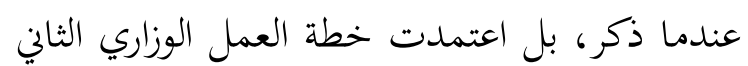

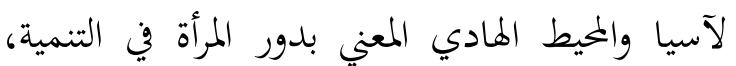
المعقود في جاكرتا من7 - 14 حزيران سنة 1994 ومن اهم اهدافه الموسومة تمكين المرأة من الاشتراك

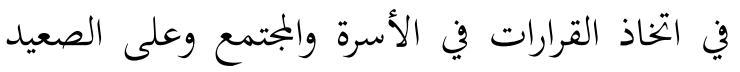

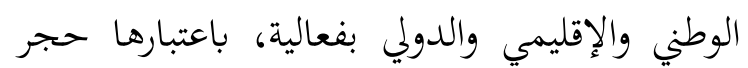
الزاوية في التنمية المستدامة والدور الاستراتيجي للمرأة الفقر (61). في الحد من
للجمعية اكدت على الكثير من الأمور ومن أهمها هي النساء والفقر، وتدريب المرأة، فضلاً عن المرأة

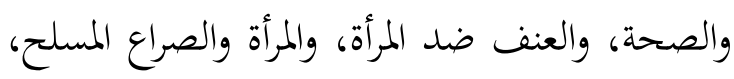

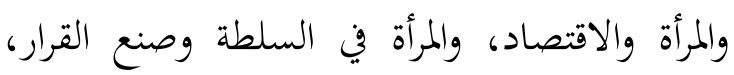

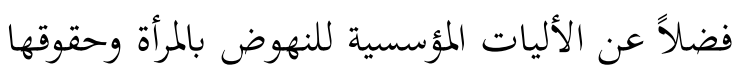

كما اعترفت بأن لديها المسؤولية الرئيسية الكاملة عن:((تنفيذ استراتيجيات نيروبي (54) التطلعية

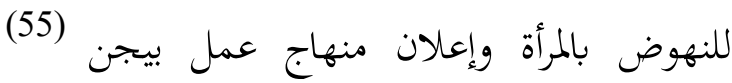

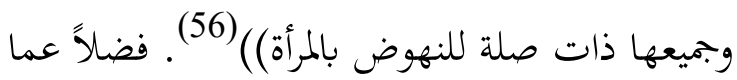

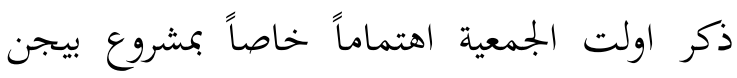

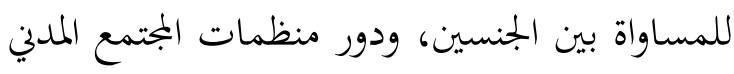
ولاسيما غير الحكومية والمنظمات النسائية لتنفيذ هذا الإعلان، وأكدت على دور الرجال في هذا

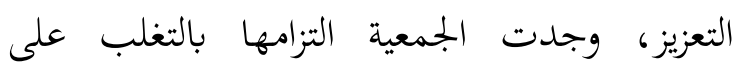
العقبات التي واجهتها للنهوض بالمرأة وتعزيز وحماية البيئة الوطنية والدولية، وعملت جاهدة على تنفيذ عمل بيجن بهدف الجمع بين كل الاطراف المعنية

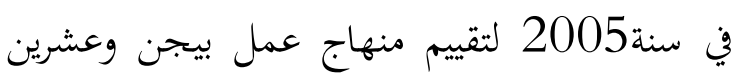

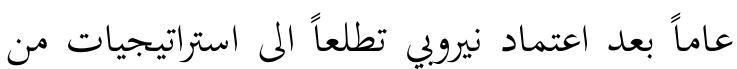
اجل النهوض بالمرأة (57).

عرض البروتوكول الاختياري الملحق باتفاقية

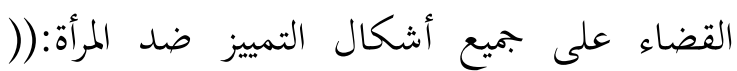

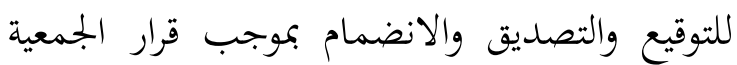

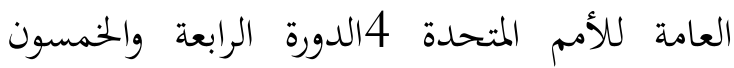
بتاريخ 9 أكتوبر[تشرين الأول] 1999 تاريخ بدأ النفاذ 20ديسمبر [كانون الأول]2000،وفقاً

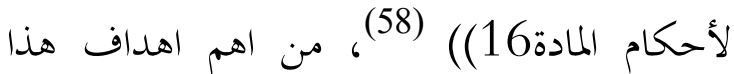


المرأة فقـد وقعت بقرارهـا المرقم 67/55 لتنفيذ بنود مبـادئ قمـة مـونتريال ســة 2002 لحقـوق المـرأة الاقتصادية والاجتماعية والثقافية الذي عقد في كندا

امــا بخصـوص المواثيـق العربيـة الـتي تناولـت

قضية المرأة كان للميثاق العربي لحقوق الانسان قراراً صــدر عــن بجلـس جامعسـة الــدول العربيــة في 1994/9/15 المادة الثانية، ولكنها وثيقة لم تدخل حيز التنفيذ66).

المبحث الثاني: الحقوق الإنسانية للمرأة غير المسلمة في الفقه الإسلامي

بمـا انه تعتبر حقوق الإنسـان قديمة بقدم البشرية نفسهـا، فقـد ظهرت بوادر في المجتمعـات البدائية ثم تبلـورت عنـدما عـاث الإنسـان في ظل الحضـارات القديمـة الفرعونيـة والاغريقيـة والرومانيـة وتعـددت اشكالها وملامحها، وإن كان الأفراد غير متساويين في الحقوق (67)، وبعد ذلك تطور حقوق الإنسـان مع ظهور الأديان ومنها السماوية. وبمـا إننـا بصــدد الــين الإسـلامي، ولأن حمايـة

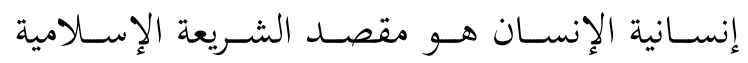

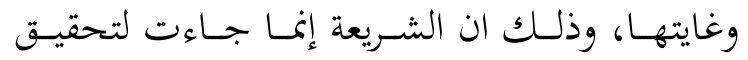

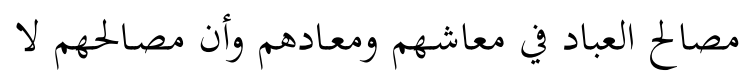
تحقق إلا بحماية الضروريات الخمس( الدين، النفس،

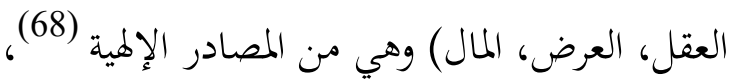
لابد من الوقوف عند حقوق المرأة الإنسانية بصورة
ومن بين أهم هذه الاعمال كانت المحافظة على الحالة الصحية للمرأة في المنطقة حيث تزايد آنذاك خطر الاصابة بفايروس نقص المناعة البشرية، وكذلك تلوث البيئة بسبب الإشعاع النووي وحرق خزونات الأسلحة الكيميائية التي كان لها الأثر السلبي على البيئة بصورة عامة وعلى المرأة بصورة خاصة، فضلاً عن قرار خاص في مكافحة محو الأمية، وإدانة التعسف والضرب الجسدي بموافقة

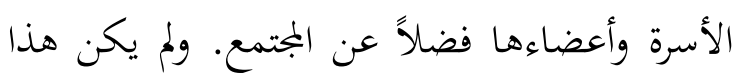

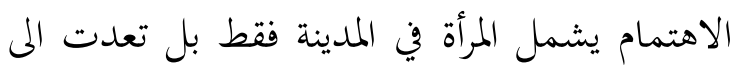
المرأة التي تعيش في الريف، ونوع عملها في الحقول الريفية، ودوره في تنمية اقتصادها، وهل هي المعيلة لأفراد الأسرة، أم هناك من يعيلها. فضلاً عن تعزيز فرص العمل للمرأة في الميادين المختلفة، في الزراعة والصحة والتعليم وما شابه ذلك لتحصل على استقلاليتها المادية(62). واصلت الجمعية العامة للأمم المتحدة برابجها المتعددة في حماية المرأة والقضاء على جميع أشكال التمييز ضد المرأة في قرار180/34 المؤرخ في 18 من كانون الأول سنة1979وبدأ تنفيذه في 3 من أيلول سنة 1981 بتوقيع الدول الاعضاء وكان ذلك في ثلاثين مادة (63). صـــرت وثيقـة الامــم المتحـــة حــول الاهـــاف

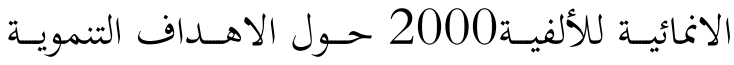
لتعزيز المسـاواة بـين النسـاء والرجـال، وتمكـين وزيادة

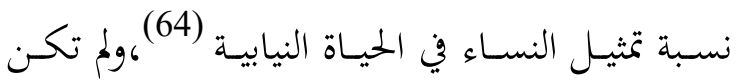
هنالك عوائق تقف حائلاً امام قرارات الجمعية العامة للأمـم المتحـدة في اتخـاذ قرارات بشـان حمايـة حقوق 
(74) ،وبدأت الديمقراطية بصورة اوضح في الخطاب القرآني لحرية الممارسة العقائدي في المجتمع الإنساني المتعدد العقائدي|آ الله مطلق الحرية للإنسان في اقتناء الإسلام ديناً، دون أي إكراه، وهذا واضح في قوله تعالىُّأ

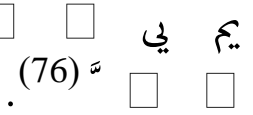

كما يدعو الاسلام الى التعامل بالتي هي الاحسن مع غير المسلمين، أي بالحكمة والموعظة

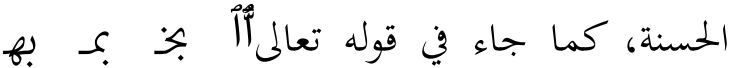
تجّت "َ (77) . وإن يعتبر خصماً، وإذا وقع بينهم اختلاف في الرأي والهجر يجب ألا يكون جدالاً عقيماً، لأن الاسلام يدعو اتباعه الى التمسك بالقيم والأدلة المنطقية وإجراء الحوار بالحكمة والموعظة الحسنة آلّآ

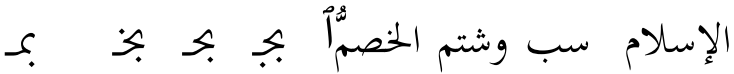

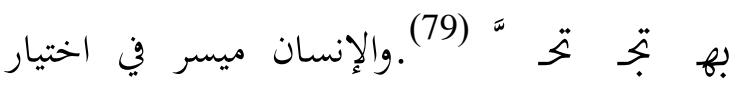
طريقة مسيره في الحياة دون أي إكراهُآ (80)

كما أزم الإسلام المسلمين وغير المسلمين بالحفاظ على دور العبادة، ومنعت الممارسة القسرية ضدها، كما يتضح ذلك جلياً في قوله تعالهُاً ليى

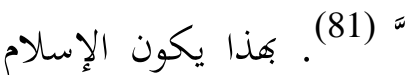

باطلاً في حالة الاستكراه على اعتناقه، بمجرد وجوده في دار الإسلام(82) كما نجد ذلك في في النصاه القائل:(( ولو أكره مستأمن على إقراراه به، أي
عامــة في النصــوص القرآنيــة والأحاديــث النبويــة الشريفة، وفق محاور متعددة منها:الححور الأول: الإنسان في الفكر الإسلامي: كرم الله الإنسان بالعقل والنطق والتمييز و والصورة

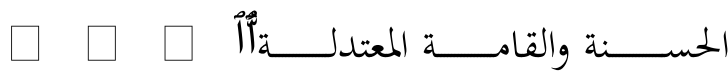<smiles>[As][Al][As][As]</smiles>

الإنسان(بالجنسين/الذكر والأنثى) في الإسلام فضلاً عمـا ذكـر البعـد العقلـي والبعـــ الحضــاري، بكونـهـ

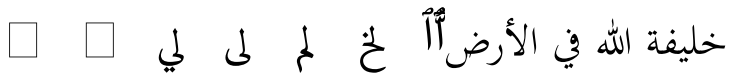

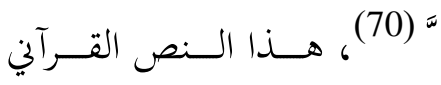

الصريح واسع النطاق يشمل البشرية جمعاء بمختلف العصسور التاريخيـة، مـع التبـاين في الإنتمـاء العقائدي ليدي والفكري وما شابه ذلك. وفضلاً عن مبدأ الاستخلاف هذا، حصل الإنسان على مكانة رفيعة تليق بالتكريم الإلهي له

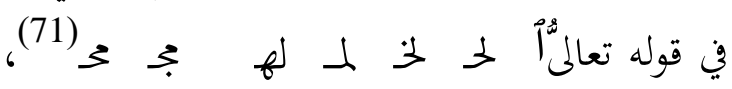
بهذا يكون مفهوم الإنسان في القرآن الكريم الذي لهي هو مصدر التشريع في الإسلام، قد تعدى حدود التضييق التي رسمها البشر على الأرض، فهو خليفة الله في الأرض، وفق منهج الاستعمار، فضلاً عن الن وظيفته على منهج الإعمار في الأرض، بغض النظر عن طريقة تفكيره في عبادة الله.

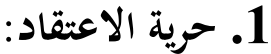

قرر الاسلام حرية الاعتقاد لكل إنسان في قوله

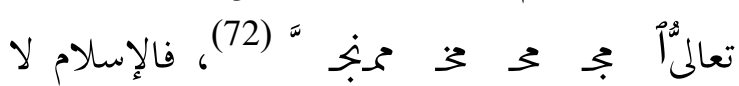
يدعو الى قسر الإرادات (73) ، وحملها على اعتناقه S.

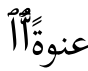


جاء هذا القول في وصيةً أخرى:(( ولا تعقروا بكيمة،

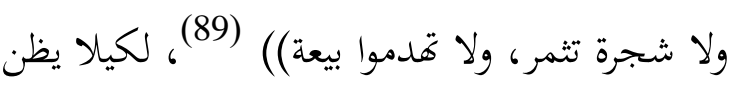
ان عداوة القوم تُبيح بعض صور الفساد، فالفساد

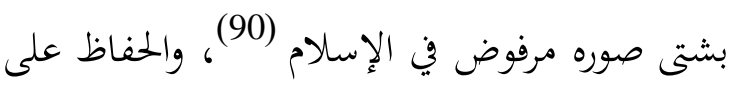
دور العبادة لغير المسلمين في كل الاحوال وخاصة في حالة الحرب (91).

حرص النبي (م) كل الحرص على غرس الأمانة ونبذ روح الطغيان والتمرد والعنفوان في نفوس أصحابه، والمعاملة الإنسانية في حالة الأسر (92) حين قال:(( من أمن رجلاً على دمه فقتله، فأنا بريٌّ

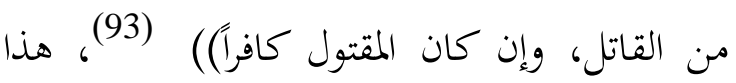
الحديث في قمة الروعة والإنسانية لتهدئة الورع في حالات الغضب لمنع حدوث الكوارث، وصد ويلات الحروب (94) وإن وقع التدافع بين الحق

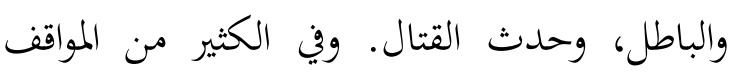
أكد الرسول(م) المعاملة المثلى مع الأسرى، ومنع من ايذائهم، او قتلهم (95). بدأت صورة التسامح أكثر وضوحاً في حالة طلب الأمان، إن جاء الطلب من قبل أحد

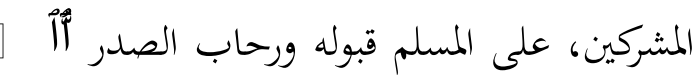

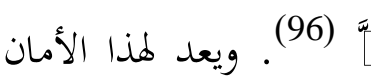

صور متعددة تضمن فيه حقوق غير المسلمين( الاقتصادية والاجتماعية والسياسية.......) (97). وفي ديار غير المسلمين لا يجوز اجبراهم على

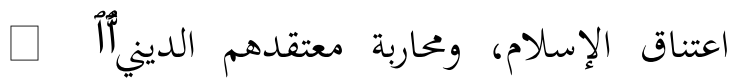
بر

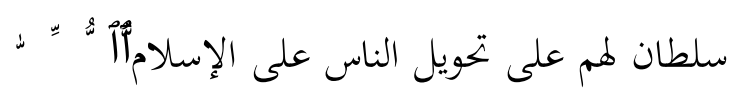

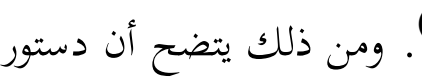

بالإسلام لم يصح منه؛ لأنه ظلم، فلا يهكم بإسلامه حتى يوجد منه مايدل على الإسلام به طوعاً)) (83). 2. إدانة الفساد في الجتمع:

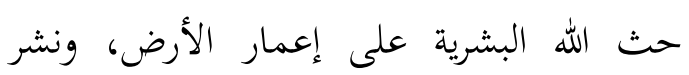
الألفة والمبة بين الناس باختلاف أجناسهم

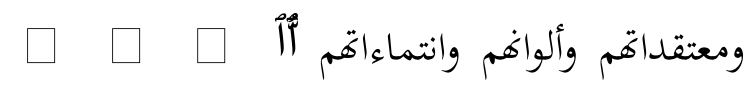
. $\mu$ هنا تتضح الصورة على الرغبة الملحة في الديانة الاسلامية على التعايش السلمي في الجمتمعات البشرية المتعددة الأجناس والأديان. وفي النص القرآي الصريح الدال على اهمية بناء المجتمع السليم القائم على الإنصاف، ومنع قتل النفس البشرية لأي سبب كان، وبدون مشروعية، وأدان الاسلام فكرة الفساد في الأرض، وقتل الإنسان، ومنعه من التمتع بالحياة التي هي هبة إلهية لا يمق لأحد ان يجرده منها، كما هو واضح في قوله $\square$ i

ي

$(85))^{\bar{x}}$

3. المعاملة الإنسانية في الحروب:

لم تكن حروب الرسول(م)حروباً تخريبية عملاً

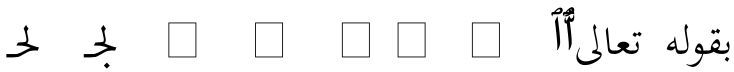

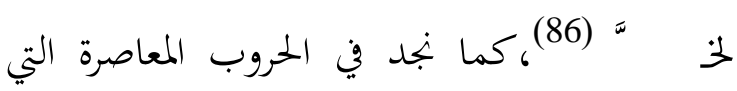
يجرص فيها المتقاتلون على إبادة مظاهر الحياة لدى خصومه (87)، يتضح ذلك جلياً في وصية الرسول(م) لأحد جيوشه:(( ولا تقطعن شجرة، ولا

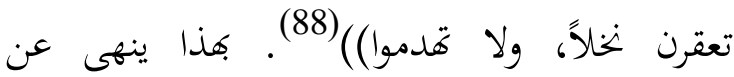
الإفساد في الأرض، وإن كانوا في حالة حرب، كما 
جارهُ بوائقِهُ (106)()()(107). (بذا حرص الإسلام على توفير الامان في المجتمع الإنساني.

\section{5. الحقوق العامة لغير المسلمين في الإسلام:}

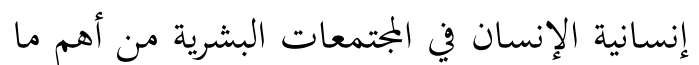

اكد عليه الإسلام، في حفظ الأمن والعيش لهم في ظل المجتمع الذي يسوده الطابع الإسلامي، فقد حث الرسول(م) المسلمين على عدم إيذاء غير

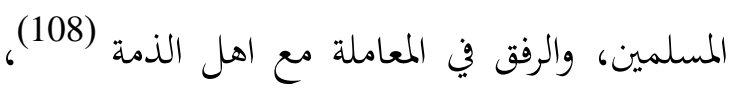
حتى لا يظلموا ولا يؤذوا ولا يكلفوا فوق طاقتهم، ولا يؤخذ شيء من اموالهم إلا بحق يجب عليهم، فقد

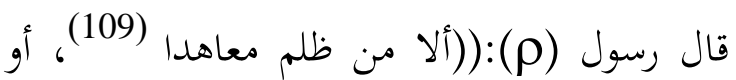
انتقصه، أو كلفه فوق طاقته، أو أخذ منه شيئا بغير طيب نفس، فأنا حجيجه يوم القيامة)) (110) بهذا جعل رسول الله الغير المسلمين ضمن حمايته الشخصية، في هذا الحديث تهديد للمخالف، وضمان لحقوق غير المسلمين. فضلاً عن هذا فقد أولى الإسلام اهتماماً خاصاً بحقوقهم في الحريات العامة في المجتمع من الحرية الاقتصادية والسياسية والاجتماعية والثقافية وغيرها عندما خاطب الله المجتمع المسلم بإبداء النصيحة وجهر الحق والصدع عن الخوفُّاً نى ني

يعتبر الرسول(م)قدوةٌ للمسلمين وعليهم الاقتداء بجميع ما آتى به من الاقوال والافعال، فقد كان من عاداته زيارة جيرانه وإن كان على غئ غير دينه (112)، ولم يمنع الشاب اليهودي من العمل بكوزته وقام بعيادته أثناء غيابه بسبب المرض (113).
المسلمين يرفض رفضاً قاطعاً إكراه احد على اعتناق

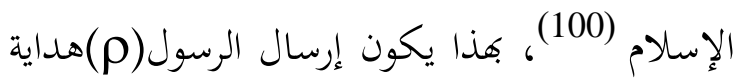

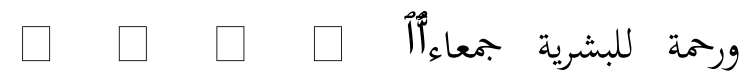
"َّ (101). على الرغم من الاختلاف الواضح بين متطلبات البشر على وجه الأرض، إلا أن الهدف المشترك الأسمى بينهم وهو الخالق(الله)

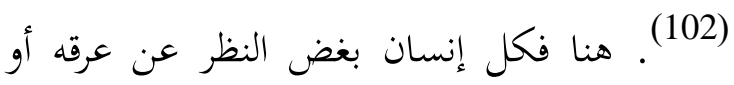
لونه أو انتمائه الاثنيّ أو دينه في نظر الإنسان كرامة لا تنتزع منه (103). 4. حق الجوار: من الاخلاق السامية التي أكدت عليها المبادئ الإسلامية، هي حُسن الجوار، وآداب المعاشرة بغض النظر على درجة الالتزام في تطبيق مبادئ الإسلام، ففي حديثين نبويين يثبت صحة ما ذهبنا إليه، فقد ذكر:(( أن رجلاً ق قال لرسول الله(م))إن فلانة تُذكر من كثرة صلاتحا وصيامها وصدقتها، غير أها تؤذي جيراها بلساها، قال ((هي في النار)). قال يا رسول الله؛ فلانة تُذكر من قلة صيامها وصدقتها وصلاتَا،

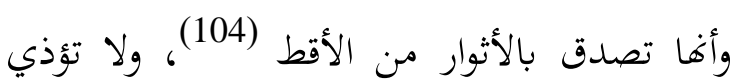

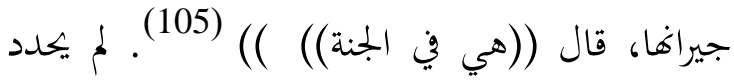
هنا معتقد وفكر ودين الجار، ومنع الإيذاء ولو باللسان، فكيف بالاعتداء على الأرواح والأموال.

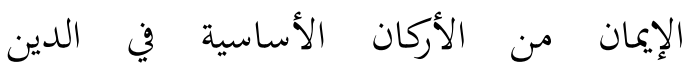

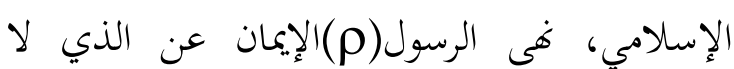
يطمئن اليه جاره، فضلاً عن الذي يؤذيه، قال رسول الله(م):(( والله لا يؤمن، و الله لا يؤمن، و الله لا يؤمن، قيل من يا رسول الل؟ قال(( الذي لا يأمن 
شرعية (الزنا) سيعاقب وفق الفقه الاسلامي والنص القرآنئiآ

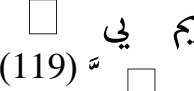

تكون العقوبة أشد إذا تعرضت المرأة بالإكرا

الى ذلك 120)،وإن تم الزواج بأي صيغةً من صيغه أوجب الإسلام بمبادئه السامية مراعاة حقوق الزوجة وهى عن ضرب الزوجة بأي شكل من الأشكال، وخاصة الضرب المبرح، لأنه سوف يؤدي الى لى لهرب مشاكل نفسية وجسدية تعيق عجلة الحياة امامها

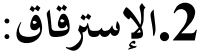

لا ننكر ان الاسالام في بدايته لم يمنع الاسترقاق، فقد كان من الجائز سبي أسرى الحرب، بل كان يمكن من حيث المبدأ تطبيق ذلك حتى على المدنيين إذا قررت السلطة العسكرية أو السياسية أخذهم

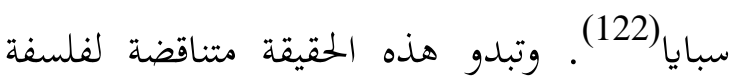
الاسلام التي تقوم على الحرية والمساواة، ولكن علينا

النظر الى الاسلام في سياقه التاريخي. عند ظهور الإسلام كان الاسترقاق عادة شائعة في العالم كله، وكان من اهم مصادره الحروب، فلم يستطع الاسلام أن يتخذ موقفاً مناقضاً كلياً للوضع

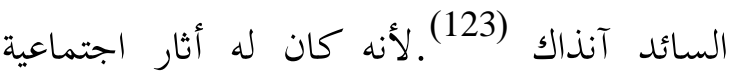
واقتصادية وخيمة لذا كان على الاسلام معالجته تدريجياً وبدليل اختفاء أمر السبي في عهد الخليفة عمر بن الخطاب(ح)صاحب المقولة الشهيرة في التاريخ:((متى استعبدتم الناس وقد ولدقم أمهاهم

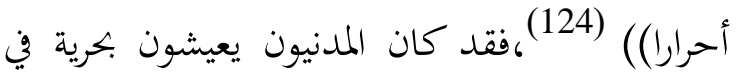

الخور الثاني:حقوق المرأة في الإسلام: جميع ما عرض في المحور الاول يضمن للمرأة حقوقها في الإسلام بكوفا لب المجتمع، وهي إنسانة لا تمييز بينها وبين الرجل في الحقوق والواجبات

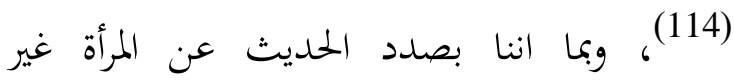
المسلمة، فلا بد للإسلام ان قد وضع قواعد خاصة بها تتمتع فيها بحرية العيش وفي الممارسة العقائدية، والاقتصادية، والاجتماعية وتولي الوظائف ضمن سيادة المجتمع المسلم. لعدم الخروج من لب الموضوع سوف نتوقف على البعض من المحاور التي تخدم

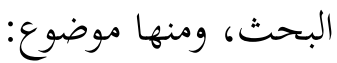

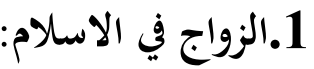
لا شك ان العلاقة بين الرجال والنساء، وما يترتب على الزواج من اهم ما بني عليه الاجتماع الإنساني، وقد اهتم الإسلام بتنظيم العلاقة بين الجنسين وإقامتها على قواعد العدل، ومراعاة الفطرة، ومتطلبات الحياة الواقعية، وليس مجرد الارتقاء الى مثالية لا يمكننا الالتزام بها (115). والذي يهمنا هنا هو التزاوج بين المسلمين وغيرهم من الأديان، فقد وضع الشرع الاسلامي ضوابط تقييد لهذا النكاح كما هو واضح في النص القرآني القائلَآْ

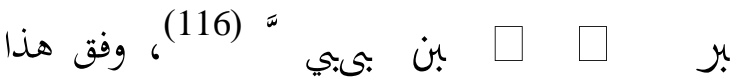
النص لا يوجد اي زواج او إقامة علاقة زوجية بين الجنسين على ضوء الاختلاف في الدين (117) و وإذا تم الزواج الفاسد او الباطل فهناك عواقب وخيمة يتحملها المذنب، وحكمهما واحد في الفقا لفه الاسلامي (118)، وإن أقام الإنسان علاقة غيان 
مارست صفية بنت عبدالمطلب العمل نفسه حين

أعتقت جارية على الرغم من أغها قد اذتها (132)، وكانت أسماء بنت ابي بكر تعتق العبيد في مناسبات مختلفة، فمثلاً في حالة المرض كانت تعتق:(( كانت

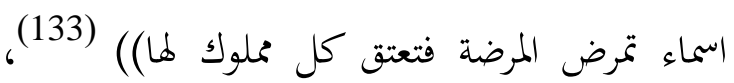
وأعتقت هند بنت عبدالمطلب في يوم واحد أربعين رقبة (134) هنا كان العتق من باب عبد الصدقة والإحسان (135)، نجد أتفاق العالم المعاصر على لئل تحريم الاسترقاق بدءاً من معاهدة إلغاء الرق في العالم سنة 1952 (136) أما عن المعاملة الانسانية للعبيد والإماء والمملوك في الإسلام، فقد تعددت النصوص التي تؤكد على معاملتهم بالمثلى،سنكتفي بذكر القليل محا يثبت لئل

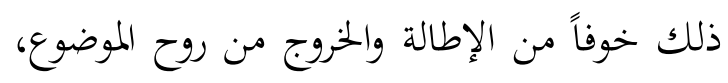
فقد منع الرسول (م) العنف الجسدي حين قال رسول الله:((من لأمكم من نملوككم فأطعموه محا تأكلون واكسوه مما تلبسون ومن لم يلائمكم منهم

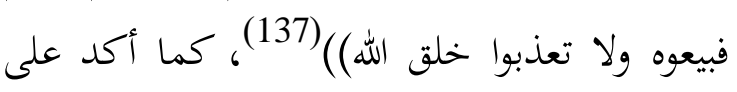
ضرورة مراعاة الحالة النفسية والمعنوية لهم كما يتضح في قوله:(( لا يقل أحدكم أطعم ربك وضئ ربك اسق ربك وليقل سيدي مولاي ولا يقل أحدكم عبدي أمتي وليقل فتاي وفتاتي وغلامي)( (138)، كما حرم الافتراء عليهم:(( من قذف مملوكه وهو بريء مما قال جلد له يوم القيامة حدا)( (139). ووضع الاسلام شروط وقواعد بخصوص ملك

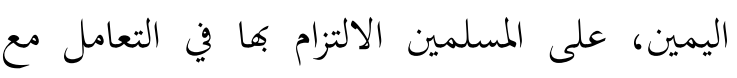
العبيد والجواري، حيث متطلبات ذلك العصر، ليمك،
الأراضي التي أستولى عليها المسلمون مقابل دفع الجزية، والتي عدت ضريبة الرأس يدفعها غير المسلمين وبأموال زهيدة لقاء حصوهم على جميع الخدمات من المسلمين من حفظ الأمن والعدوان الم الخدمات الأخرى (125). ولمراقبة التطور التاريخي لموضوع الرق في الإسلام، قد نستنتج أن الرسول قبل

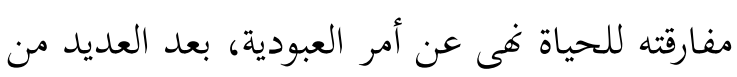
المحاولات على أرض الواقع لمعالجة خطر الاسترقاق في المجتمع. حيث بتحر الملاحظة ان التشريعات التي صدرت في فجر الإسلام كانت تهدف الى الحد من آثار هذا النظام إلى أقصى حد ممكن، فالكثير من الآيات القرآنية والأحاديث النبوية مجدت إعتاق العبيد كعمل من اعمال البر والتقوى، والكفارة من

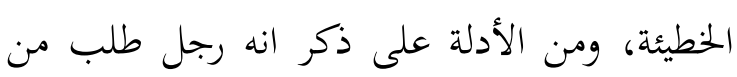
الرسول(م) أن يرشده لطريق يؤدي به الى الجنة،

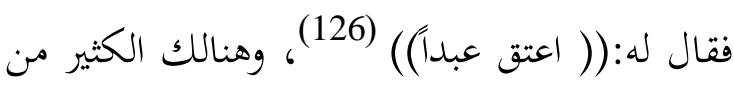
الاقوال النبوية التي تؤكد على ذلك منها قوله:((من أعتق نصيبا له من العبد فكان له من المال ما يبلغ قيمته يقوم عليه قيمة عدل وأعتق من ماله وإلا فقد

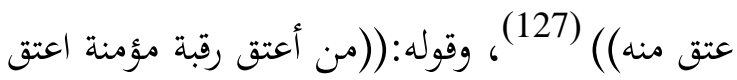
الله تعالى بكل إرب منها إربا منه من النار حتى إنه ليعتق اليد باليد، والرجل بالرجل، والفرج بالفرج))

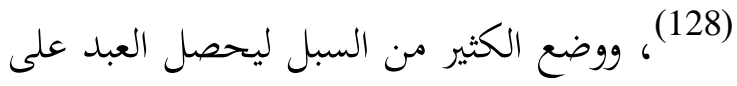

حريته احياناً وكان منها عن طريق المكاتبة (129). مع معالجة الإسالام لموضوع الاسترقاق منذ بواكر هوضه، وهناك الكثير من الأدلة على ذلك ومنها انه

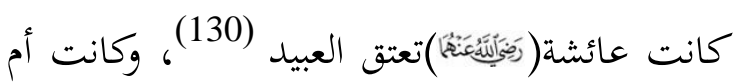
سلمة قد أشترت ناعم بن أجيل وأعتقته (131) 
بالصلاة والصوم، وصلت اخرها الى عرض صورهن على مواقع خاصة تعمل تحت اشراف التنظيم كسلع تباع وتشترى في مواقع تسمى - سوق الخلافة-

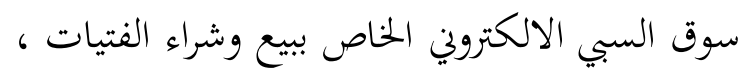
فقد بيعت بأبخس الاثمان، في وقت يجاهد العالم لإنصاف المرأة وتعزيز مكانتها في المجتمع في قرن حقوق الانسان وضمان حقوق المرأة، كانت الفتيات الايزيديات ولازلن سلع تعرض على صفحات الكترونية يتم الاشارة الى مزاياهن وعرض صورهن لكي يتم المزايدة عليهن · فضلاً عن هذه المآسي والعيش تحت رحمة النزوح وين مخيمات لا تتوفر في العديد منها ظروف العيش البسيطة. تتضح الصورة هذه في الاستشهادات الميدانية لعينات من الناجيات من مختلف الأعمار، واللواتي باستشهاداتَن كشفن الستار عما عاشتها من مآسي تاركةً الأثر السيء في ذاتها، جسدياً ونفسياً وفكرياً ودينياً. للوقوف على كل هذا لابد لنا من الاطلاع على حياة الناجية قبل هذا العدوان، وبعده، وذلك وفق التقسيم الآتي:-

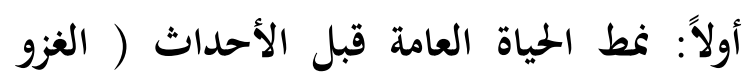

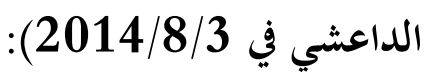

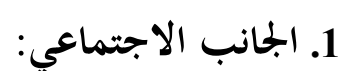
اجتمعت أقوال جميع العينات على العيش الرغيد في ظل مؤسسة الأسرة، وبرعاية الأب الذي كان يعيل أفراد الأسرة، تلك الأسرة التي كانت تتألف من الأبوين والأولاد وزوجة الابن والأحفاد، وتباينت الاستشهادات بين العيش في الأسرة الكبيرة، كما في ولي ولئ ولئ

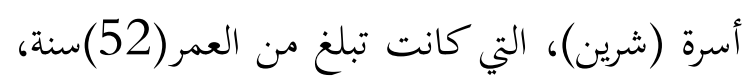

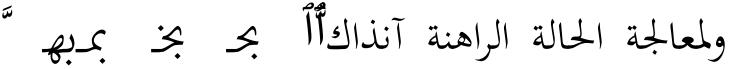
(140). فلهذا ثبت أن الرسول جعل يوصي أمته في مرض الموت بالصلاة وما ملكت أيمانكم، فجعل يرددها حتى ما يفيض بها لسانه (141).

\section{المبحث الثالث: استشهادات ميدانية لانتهاك حقوق المرأة الكوردية الإيزيدية}

مع سيطرة وغزو تنظيم داعش الارهابي لمنطقة سنجار - شنكال التي تعد ثاني اكبر مركز للايزيدية

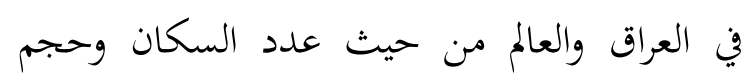
وموقع ومكانة المنطقة في 3/آب/2014. أُرتكب بحقهم ابشع صنوف الارهاب والاعتداءات .

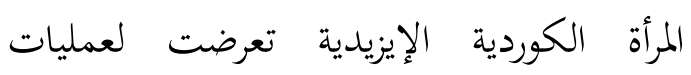
الخطف والممارسات اللاحقة التي اندرجت تحت مختلف مستويات انتهاكات حقوق الإنسان، من سجن انفرادي، وجماعي، والتعذيب وبأساليب عديدة، بتويع، بيع، سبي، اذا ان جميع الفتيات

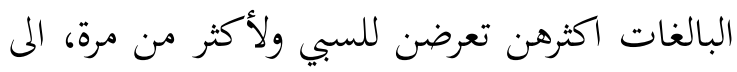
جانب البيع كسبايا بتحددت ظاهرة العبودية ايضا، اذ اجبرت العديد من النساء المتزوجات ان يصبحن عبيد - إماء في منازل ومقار تنظيم داعش في الموصل والرقة وحلب والشدادي وتلعفر والفلوجة والحويجة والبعاج، وأجبرت على العمل في ظروف قاسية جدا، الى جانب ممارسات الاعتداءات الجنسية واجبارهن على ترك ديانتهن واعتناق الاسلام عنوةً وفرض عقوبات في حال لم يلتزمن 
السعيدة، وبالعيش الرغيد الذي وفر لـ (فرحى

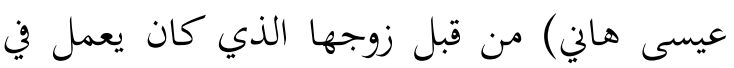

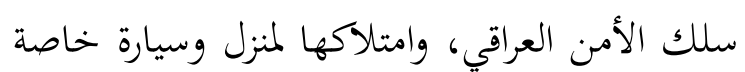

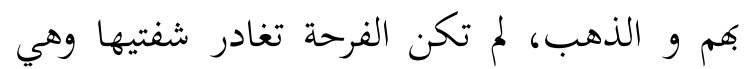

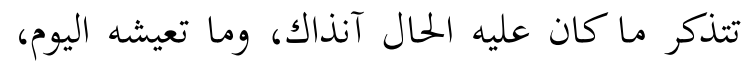

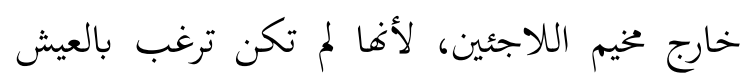
وسط المآسي ثانية.

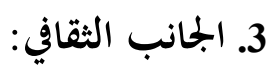

مع بالغ الأسف لم نجد بين النساء في عينات

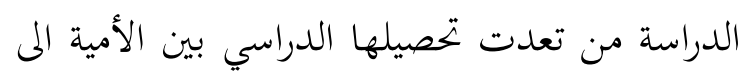
الشهادة الابتدائية،(نورا) كانت حاملة الشهادة الابتدائية، وهذا بحد ذاته يدل على دور السياسات

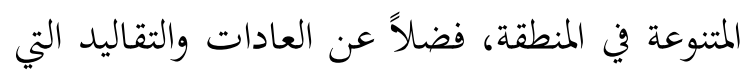

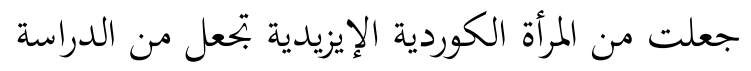
اخر اهتمامتها.

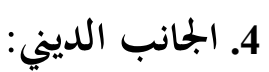
اجتمعت الاستشهادات على حد السواء على الى الممارسات العقائدية الخاصة بالديانة الإيزيدية، بالحرية الكاملة، بتعايش سلمي مع غيرهم من المسلمين، والفئات الأخرى في المجتمع، دون أي قيود

ثانياً: التغيرات الجذرية في حياة المرأة في ظل الغزو

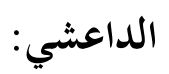

أفصح مركز الناجيات الايزيديات (143) إحصائيات دقيقة عن احداث 2014/8/3،

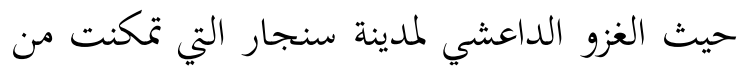

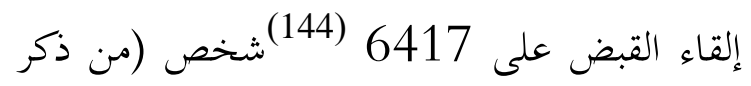

تعيش معها أخت الزوج، وأبنائها المتزوجين، وأحفادها.

وعاشت عائلة (سيران، ونورا) المتزوجتان من (نايف) في جو مليء من الدفء مع اولادهما، فضلاً عن زوجة ابن سيران(سحر) (142)، وحفيدتها

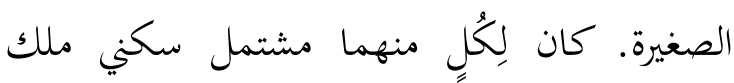
صرف يعيشون فيه، وفق روابط اجتماعية، تميزهم

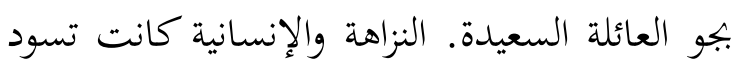

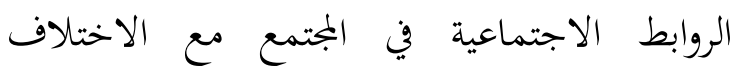
العقائدي آنذاك. - الك.

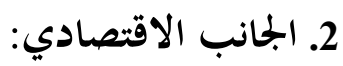
اجتمعت الاستشهادات المتنوعة للناجيات اللواتي بالرضا والسرور للعيش في مستويات معيشية مختلفة

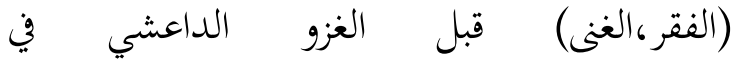
2014/8/3،حيث كانت اغلب النساء متفرغات لتدبير شؤون المنزل، ورعاية الأطفال، وتوفير الشاءل الفرات

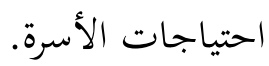
كما لوحظ ان أغلبية النساء قد حرصن على الى لمرة

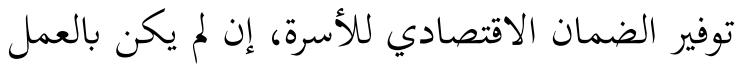
خارج المنزل بل بالتوفير والإدخار. عاشت عائلة (شرين) في ثراء فاحش بأملاكٍ لا تحصى( الأموال المنقولة والغير المنقولة)، والذهب الذي وصفته بين (2 - 3) كيلو ذهب، كانت نساء وبنات أسرتا يتزيين بها. أما(نورا) فقد تحدثت عن أسرقا التي كانت تعيش في مستوى اقتصادي متوسط، بموارد مادية

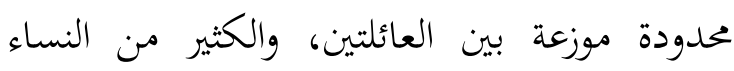
الأخريات تحدثن عن الفقر المادي في ظل الأسرة 
داعش، ومصيرهم مجهول، أثنين منهم إناث أعمارها

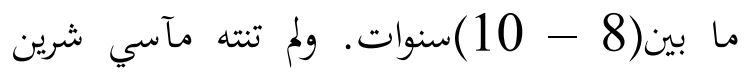

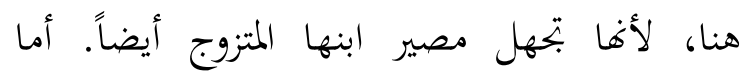

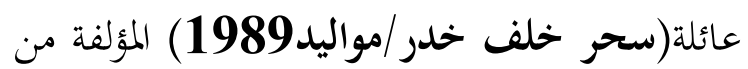

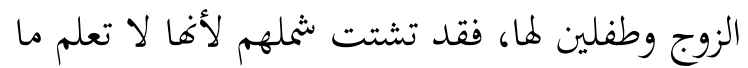
آل الل اليه مصير زوجها.

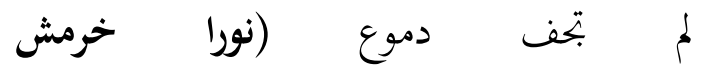
كلش/مواليد1980) خلال فترة اللقاء بها، لأنها

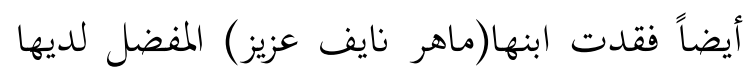

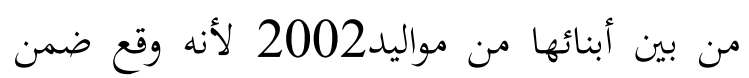
ضحايا داعش الإرهابي، كونه أصبح احد أفراد

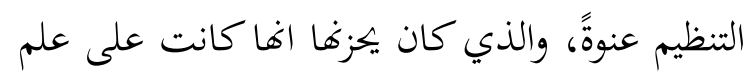

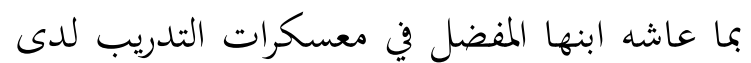

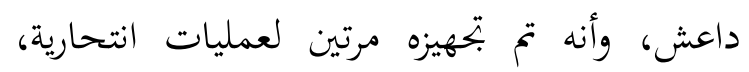
بواسطة قيادة سيارات مفخخة، لكن الأجل لم لم يوافيه في تلك الآونة بسبب عطل السيارات، وأخوه

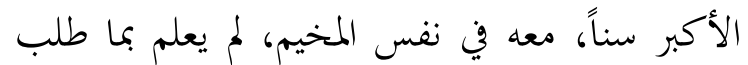

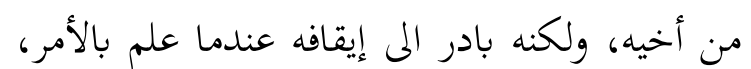
دون جدوى بسبب طغيان العدو عليهم، وكان مراراً يشكو لوالدته، ما كان يتلقاه اخوه المريض بخفقان

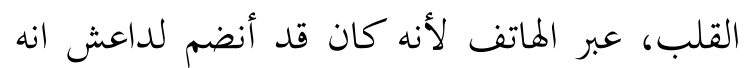

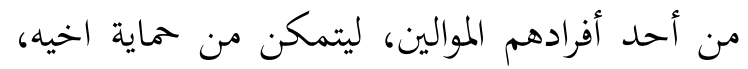

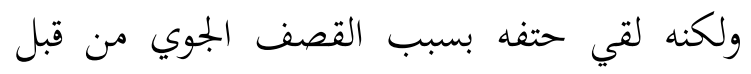

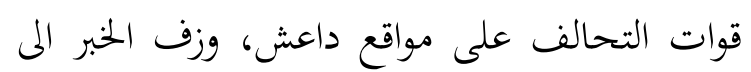
الوالدة عن طريق شريط فيديو تحتفظ به أعده داعش لابنها، في كل صورة من صوره تظهر عليه

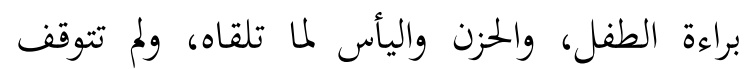

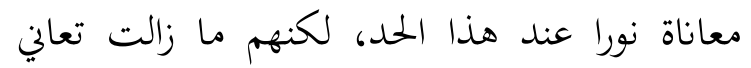

وأنثى) الذين راحوا ضحية لجرائم داعش بين المقتول والمخطوف والمفقود.

رصد البحث عدد الناجيات من قبضة داعش نهو 1159 امرأة، تعيش الأغلبية منهم في حالة

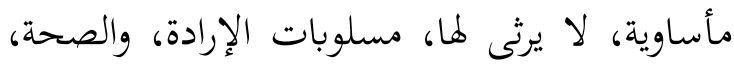

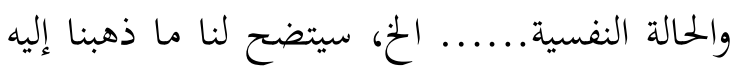

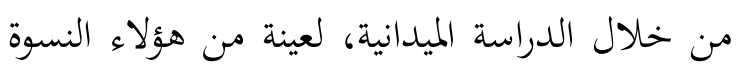

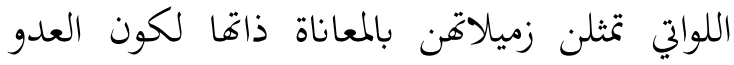

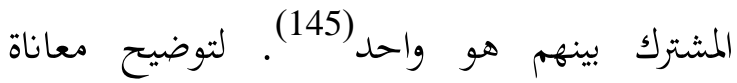
الاختلاف الفكري والعقائدي، والاجتماعي بين

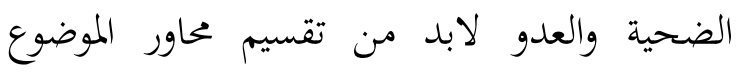

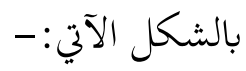

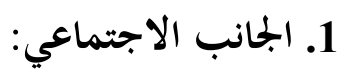
تفكك الرابط الاجتماعي والأسري لدى جميع الاجئ

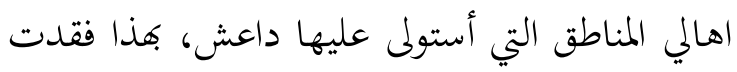

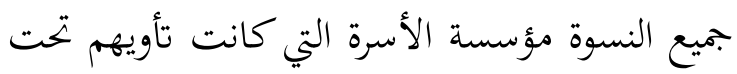

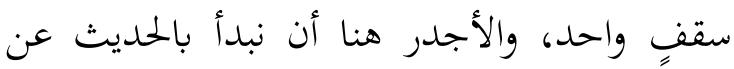

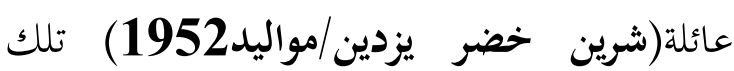

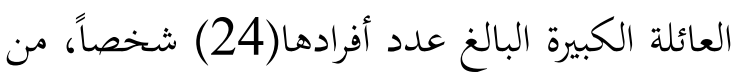

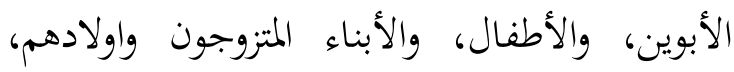
فضلاً عن ثلاثة أخوات لزوجها،لم يبق معها الآن سوى ابن، وأخت الزوج المعاقة.

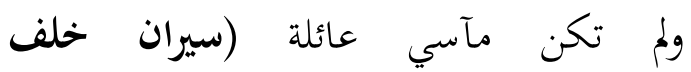
فرحو/مواليد1972) أقل مما ذكر التي كان لها من من فئن

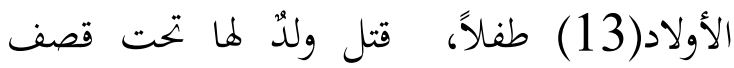
الطائرات الأمريكية على مواقع داعش، لأنه بالإكراه

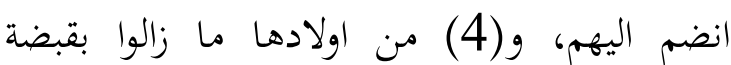


الحرية الشخصية، أمثال (زينة نايف/ مواليد 2006 الناجية2016) تدرس في مرحلة المتوسطة

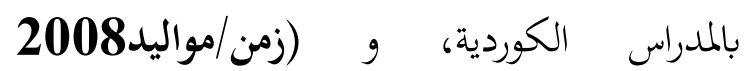
(2015) الناجية (2015)

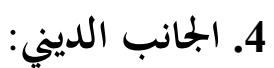
فقد الاكراد الايزيديين نحو 68 مركزاً للعبادة

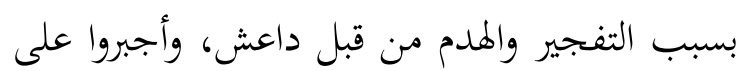

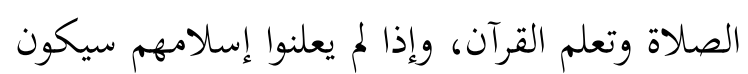

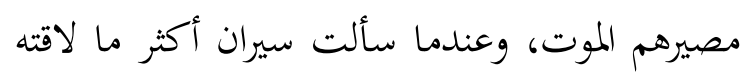
من انواع الاضطهاد من قبل داعش أثناء الأسر، الماته اكدت على الصلاة تحت الإكراه(صلاة المسلمين) من قبل الداعشي الذي اشتراها في أغلب الأحيان

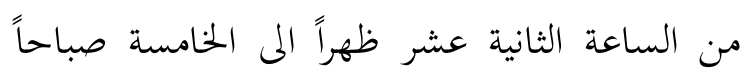

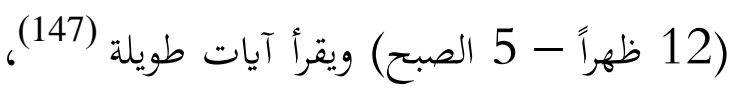

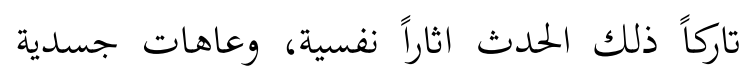
عليها، وقالت كنت اسأله، ألا يتطلب الصلاة ركن

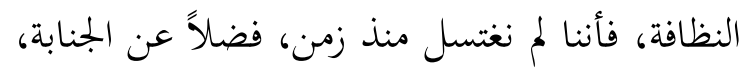

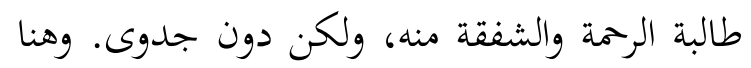

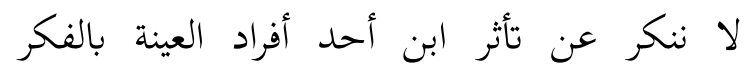

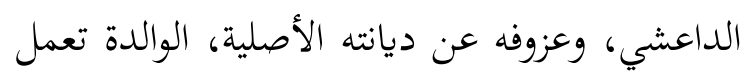

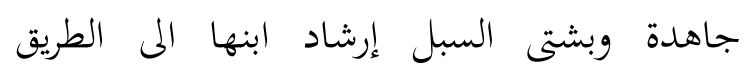
الصحيح.

توصلت الى نتيجة مفادها أن الأغلبية من

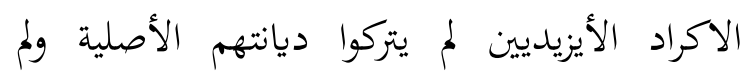

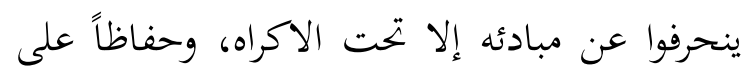

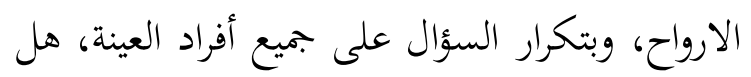
يمثل داعش الدين الاسلامي؟ كان الجواب، كلا.
أسوء مظاهر الأسى بعد تحرير ابنها الأخر من قبضة

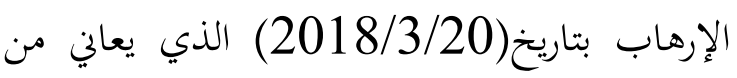
اضطربات فكرية وعقائدية، وأسرية.

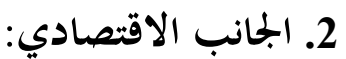
تحولت الحالة الاقتصادية الى الركود والانعدام، لدى جميع النساء في عينة الدراسة، وهن في منتصف اعمارهن كما شكلن عباً على ميزانية إقليم كوردستان العراق (146)، الأثرياء أمثال شرين تحولت عيلت حياتم من الغنى الى الفقر والشحة والعيش في منازل

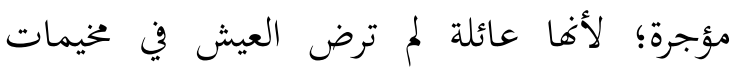

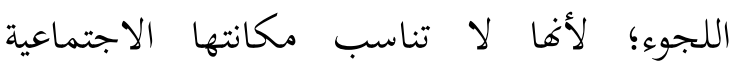
والاقتصادية المعتادة عليها.

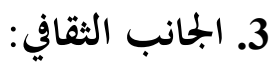

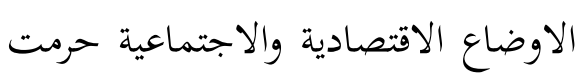
الكثير من البنات والأطفال أبسط حقوقهم في التعلم

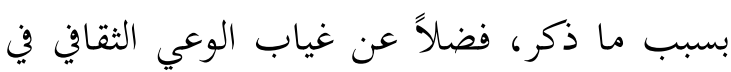

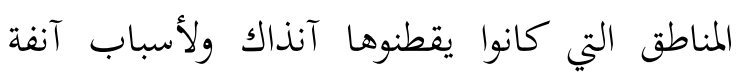

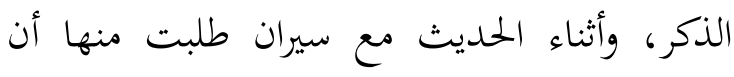

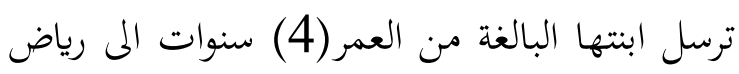

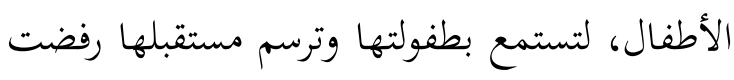
ذلك وبشدة لأسباب تحفظت بها، ورددت بانها

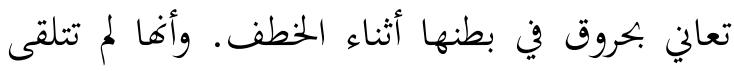

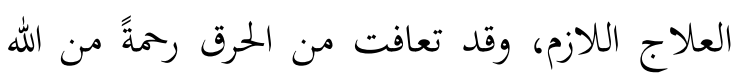
هما، مع هذا لا ننفي تلقي الكثير من البنات والأطفال الدراسة في مختلف المراحل الدراسية في

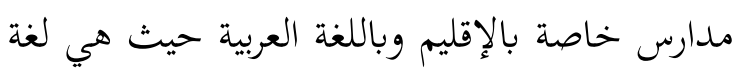

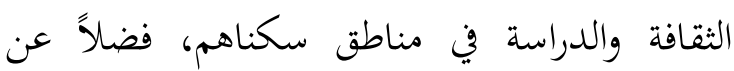
دراسة بعض في المدراس الكوردية، وذلك وفق مبدأ 
الاعتقال، لحمايتها من سبي البنات، التي عدت الخطوة الأولى من برنامج داعش في المعتقلات الخاصة بالنساء بعد عزلم عن ازواجهم وأولياء

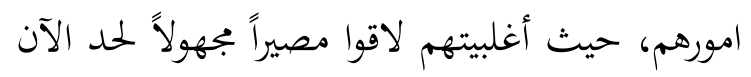
من قبل ذويهم. مع هذا لم تنجو من الاغتصاب فيما بعد ضمن الخطة الثانية من اقتناء المتزوجات أيضاً.

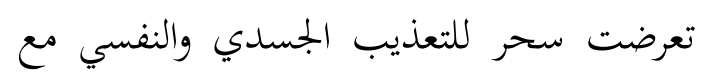
ابنتها الطفلة(عمرها سنة)، وهي حاملة اثناء القبض لكري عليها، والتي لاقت التعذيب كوالدتا لقهر الوالدة، لأها حاولت الهرب من قبضة داعشي تونسي الأصل(عمره 30 سنة) كان قد اشتراها من سوق العبيد والسبايا بثمن بتهله، وجاءت المحاولة هذه لأهما عاشت ثمانية أشهر معه، تعاني أبشع صور الإجرام من الخدمة له ولزملائه وأسرته في المنزل والمقر

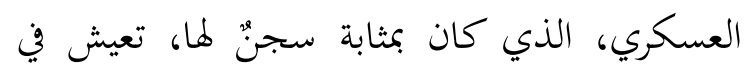
غرفة فوق سطح المقر بدير الزور وقبله في مدينة الموصل. ولم تتحول اوضاعها الى حالٍ أفضل في ظل لرئل الداعشي السعودي الأصل(عمر33 سنة) التي عاشت معه سبعة أشهر. بهذا اغتصبت من قبل الداعشي وخدمته وهي في اليوم الثاني من عملية الولادة القيصرية ، وخادمة لزوجته التي لم تكن أفضل

$$
\text { من زوجها الإرهابي في التعامل معهم. }
$$

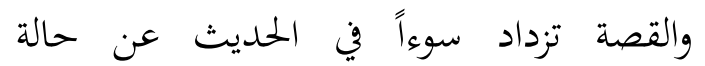

\section{(هديل/مواليد1992 الناجية في 2018) التي}

نجحت والدتا وذويها في المرحلة الأولى لإنقاذها من

السبي، وإجبارها على تمثيل دور الأمومة لأختٍ لها أمام داعش، مع الأسف لم يوفقوا، لأها سبيت في

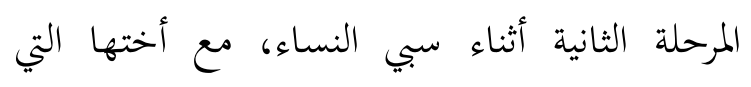

وهذه رحمة الهية، لبث روح التعايش السلمي بين أطياف المجتمع.

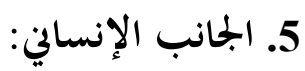
مع الأسف فقدت جميع النساء من أفراد العينة وخارجها إنسانيتهم التي سلبت أثناء القبض عليهم،

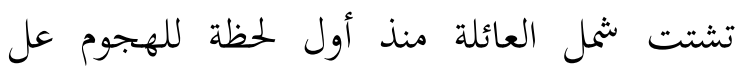
مناطقهم، باحثين عن سبل الأمان، ولكن قوة الإرهاب المنظم والمدعوم من الداخل والخارج، وقع بالأغلبية الساحقة ضحية لجرائم، تعد من أبشع جرائم الإبادة التي عاشها الشعب الكردي بمختلف عقائدهم (148) ، وأثبتت العينة أنه في أول اصطدام لهم بوجه داعش، قتل شاب و بأبشع الصور كان بقبضتهم أمام اعينهم، لبث الخوف والانصياع والإصغاء لأوامرهم. من هنا فقد الجميع روح الأمل في الحياة، وانتظروا الموت طيلة فترة الأسر في كل لحظة تفنن بها العدو بين الإرهاب الجسدي،

$$
\text { والنفسي، والصحي.....'الخ. }
$$

سلُبت الكرامة من النساء في مراكز متعددة من ولصئ سوق العبيد، أصبحت المرأة في هذا السوق سلعةٌ

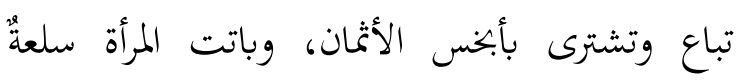
استهلاكية، كلما نفذت صلاحيتها، تباع ثانية وثالثة، وهكذا، ولم تعد للمرأة كرامة بل أداة اشباعية لاحتياجات، وغرائز الرجال، وتكالب الصراع الجنسي عليها، دون إرادة تذكر. اكثر مما يؤلم من هذه القصص المأساوية، فقدان (هديه نايف عزو مواليد 2003 الناجية 2017)

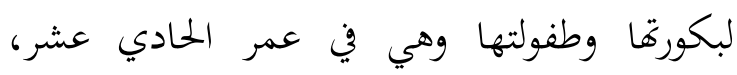
وفرض عليها الزواج من أحد أبناء ذويها في مخيمات المنادي 
للعتق، لأنه قد تسبب في وفاة شخص دون قصد، فقد كانت القوانين تتضمن،( توزيع المؤن، ذبح أربعين ذبيحة، أو عتق يزيدية، أو صوم أربعين

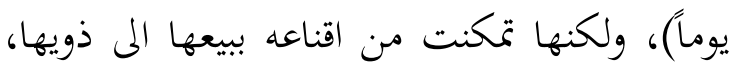
لان قرار بيعها كان لسوء أوضاعه الاقتصادية. لعبت النساء الداعشيات المنقبات دوراً في انتقاء السبيات وتفنتوا في ذلك عن طريق التمييز بين الإناث العذراء والمتزوجات، وجميلات الوجه، وحسن

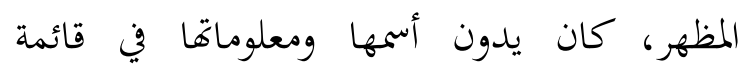
خاصة، كما كانت تفحص النساء وتسلبهم من الذهب او المال إن كان بحوزتما، وإن احتفظت بسيم كارت، وتحدثت شرين عن قتل فتاة مسلمة شيعية المذهب، كانت قد وقعت معظم بالأسر وبحوزة داعش، كان مصيرها الموت لانما رفضت النطق فأنق

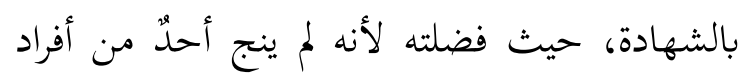

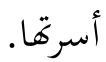
لعب بعض من أهالي المدينة دوراً سلبياً مناقضاً

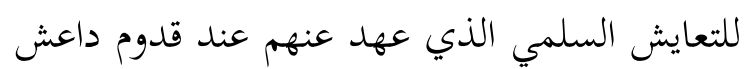
للمدينة، وذلك بالتعبير عن فرحهم بالإطلاقات النارية، وإقامة الولائم، وذلك حسب شهادة (شرين،

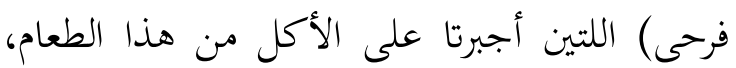
وهما في الإقامة الجبرية.

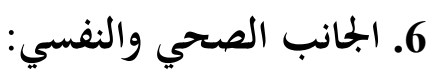
الأغلبية الساحقة من النساء الناجيات يعانين من

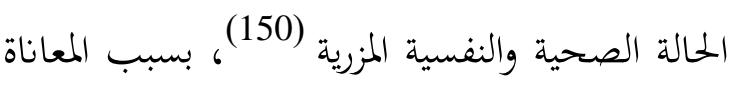

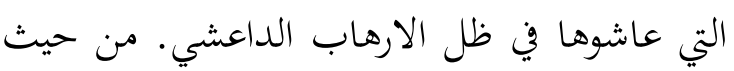
سوء التغذية، اثبت (سارو عمرو مواليد1999 -
عدت بمثابة الوالدة لها، ومما زاد الأمر سوءاً عندما

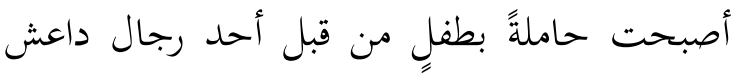

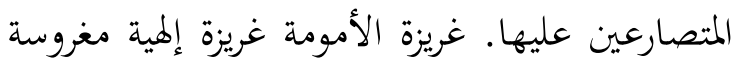

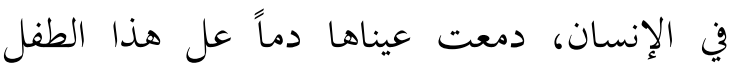
الذي أكرهت عل تركه، عند الوالدة وهي بين رممة الأسال

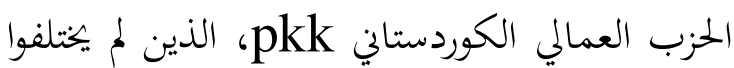
عن داعش في بعض من جرائمهم مع الناجيات، أثناء مسيرة الإنقاذ حسب استشهادات أغلبية

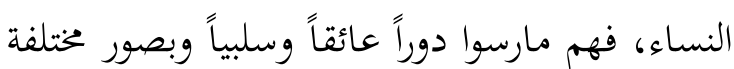
في عملية الإنقاذ(كالإتحار بالأموال - تأخير عملية الإنقاذ - وضع قيود تعجيزية امام السلطات القائمة

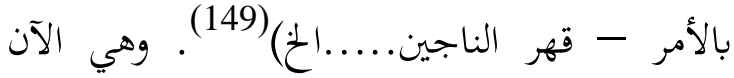
والدة لأختها، لأفها لا تستطيع أن تمحو من مخيلة

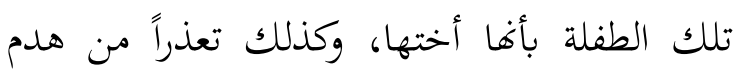
نفسيتها. المعاناة لا تفارق والدة ماهر، التي تعرضت هي الأخرى للبيع في سوق السبي بين أيدي المرتزقة،

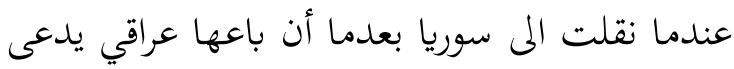

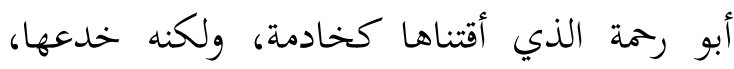

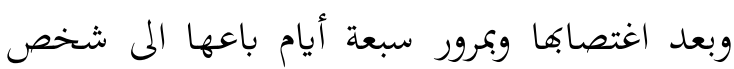
تونسي ( أبو سيف) الذي استصحبها معه الى

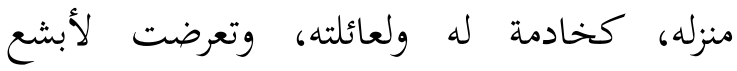
معاملات من قبل الزوجة، وتجبر على خدمة اولاده،

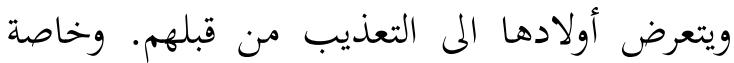

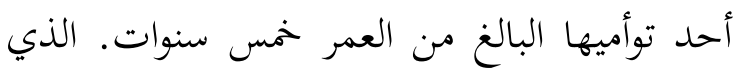
يعاني من عاهة على وجهه أثر الضرب. قرر الأخير بيعها الى داعش سوري الأصل(أبو عمر)، الذي الذي رغب في شراء جارية وعتقها وفق قوانين داعش لئش 
كبير من أفراد أهل زوجها، فضلاً عن معاناتما من

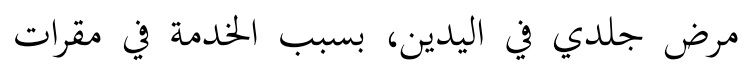

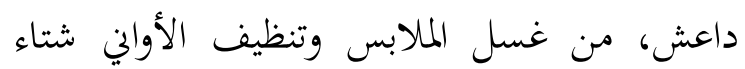

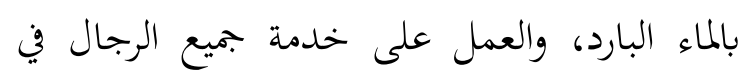
المقر وهي في اليوم الثاني من ولادة ابنها بعملية

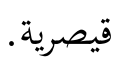

ومن بين الناجيات كانت( أم فرواس، مواليد1988 الناجية 2017) تعاني من حال نفسية بسبب قتل طفلها الرضيع أمام عينيها،

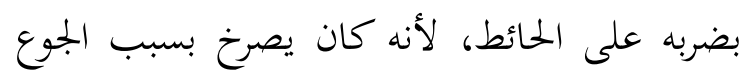

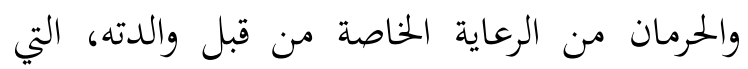
وقعت في أسر الداعشي المتعطش للجنس والجريمة. لعدم توفر أي شروط صحية في معتقلات

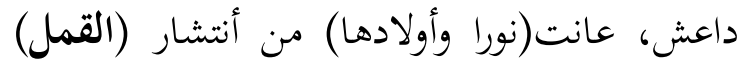
في رأسهم، عاشت مع هذه المعاناة لفترة طويلة بتحاوز الأمر الى مابعد مرحلة التحرير. - الحائمة والاستنتاجات: يمكن تلخيص ما توصل اليه الدراسة بالصيغة

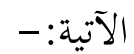

1. مبادئ حقوق الإنسان في المواثيق والمعاهدات الدولية، باتت ورقية أكثر مما هي واقعية.

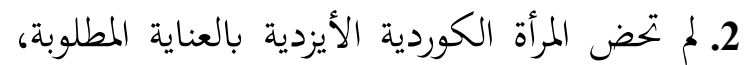

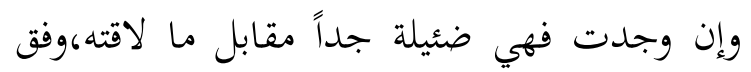

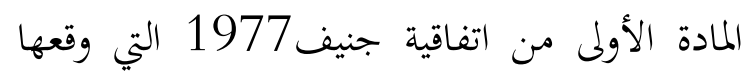
أغلبية الدول المشاركة، وأعلنت التزامها باحترام قواعد القانون الدولي الإنساني، وفي البروتوكول الإضافي الأول، بالتعاون مع الأمم المتحدة في حالة الدون الئل
الناجية في 2016)، في بداية الغزو لمناطقهم كانوا

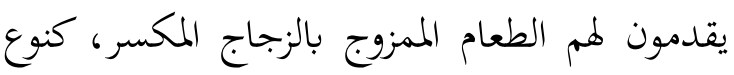
من التعذيب، والحرب النفسية، ولإصابة بالأمراض.

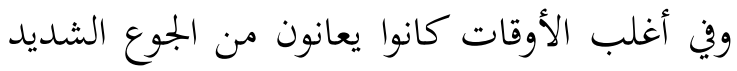

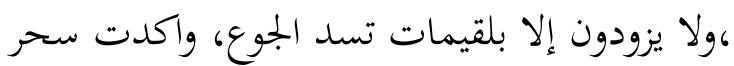
أهن أجبرن على شرب ماء المجاري أثناء وجودهن

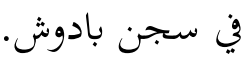
أجهضت(فادية المواليد1993-الناجية ي في 2017 )طفلاً في الشهر الخامس من الحمل، بسبب العنف الجسدي للاغتصاب المتعدد في ليلة

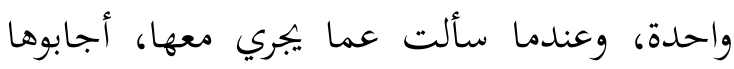

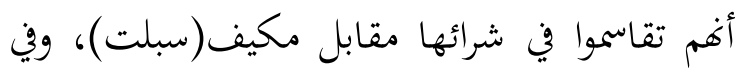
اليوم الثاني كانت هي قابلةً لطفلها الذي فقدته

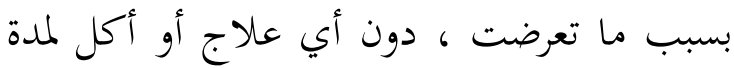

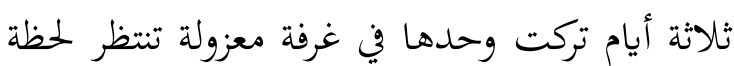
الموت. فهي هنا كانت بنظرهم فقط كانت سلعةٌ لا أكثر. والحالة الأكثر مأساوية هي في قصة(بمار الملدعوة

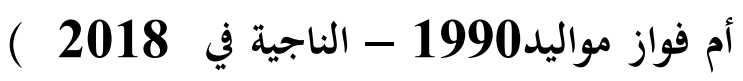
التي أصيبت بمرض الزهايمر، وفقدان الذاكرة، بسبب

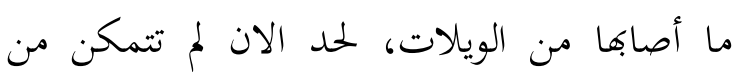

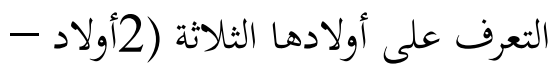
ابنة واحدة) الذين يعيشون بدار الأيتام في شيخان، لفقداغم المعيل من الأب والأم المريضة.

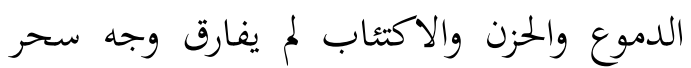
التي فقدت زوجها، وهي تعيش في مستوى دون

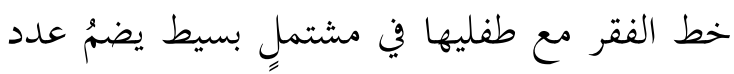


7. داعش منظمة إرهابية مدعومة بقوة دولية، تعمل لخدمة بعض المصالح الاقتصادية والسياسية الدول العظمى، عملت على نشوب الفتن الطائفية والدينية والقومية في المنطقة، حيث أستنتج ذلك، من الاستشهادات، وحركة نقلهم بين المدن، فضلاً عن تلقيهم لعلاجات طبية من الأدوية أحياناً، كما في

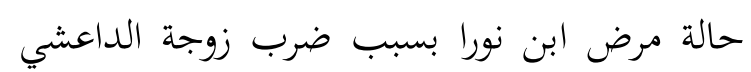
وشقيقتها له، قالت بعد تضميده في المشفى

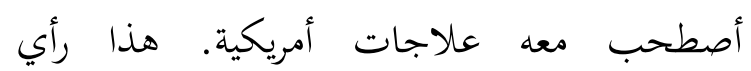
الناجيات ليس للبحث أي دليل علمي وقاطع يثبت ذلك.

8. استخدم داعش سياسية التدرج في العنف للوصول الى مآربهم، بين الوعود الزائفة والحرب النفسية، كما كانت الأم تسلب الإرادة في عملية فصلها عن أولادها، إلا من كانت تجيد اللغة العربية وتتفاوض معهم لعدم التفريق بينهم. 9. خارطة نقل المخطوفات باتت شبه موحده في

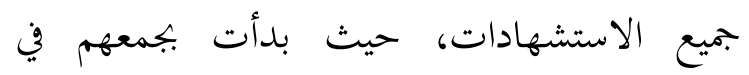
مصرف حكومي(مصرف حي النصر)، ومن ثم بفرع للحزب الكردستاني هناك، وبمرور بضعة من الأيام تم

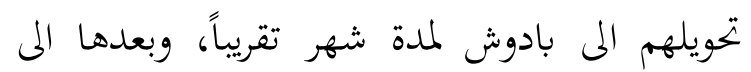
مدارس بتلعفر، وتم تثبيتهم لمدة سبعة أشهر في قرية

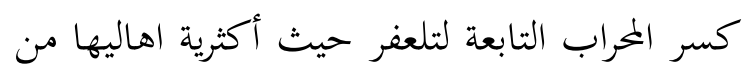
المذهب الشيعي، والبعض الأخر في أحد أحياء

$$
\text { تلعفر المعروف بـ حي الخضراء. }
$$

10. أما بخصوص عملية البيع والشراء فقد كانت تتم بسبل شتى وأسواق متعددة ومنها كانت الاسواق الألكترونية، مع هذا كان هنالك مراكز
الانتهاكات الخطيرة لحقوق الإنسان في أي بقعة من

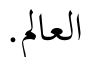
3. وفق استشهاد مدير مركز الناجيات، ان منظمة حقوق الانسان الدولية، لم تقدم لمم أي دعم يذكر، سوى اهم قاموا باختيار بعض الناجيات، للسفر الى المانيا لغرض العلاج، وقيل أن هذا الاختيار كان بمحض إرادتم، وبدون استشارة او رغبتنا، ومع الأسف كانت أغلبية النسوة اللواتي تم اختيارهن من قبل المنظمة للسفر ليسوا من ضحايا جرائم داعش،

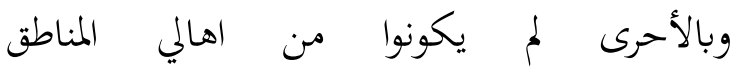
المنكوبة(سنجار وضواحيها). 4. الاحداث التي عاشتها المرأة الكوردية الأيزدية تتناقض كاملة مع المنهج الإسلامي الحنيف، والجرائم التي قام بها داعش لا تمد بأي صلة بمبادئ الإسلام، من اعمال وحشية تنكرها الإنسانية. 5. التمسنا بأنه لا يوجد اختلاف بين قواعد الشريعة الإسلامية والقانون الدولي في حماية حقوق الإنسان، من حيث الأسر، واحترام إنسانية الإنسان

6. الأغلبية من النساء الناجيات تعاني من مشاكل نفسية، وجسدية، وعاهات، تاركةً الأثر السيء في نفسيتها، كما تعيش أغلبية النساء بحالة مادية مزرية، لا يتوفر في السكن شروط صحية، وخدمات تليق بالإنسان الذي كرمه الله. ولم تكن لديهم أي رغبة للرجوع الى أراضيهم ثانية، بعد المعاناة التي عاشوها ثانية، هنا عملية الترحيل والتهجير القسري للأكراد

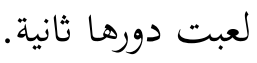




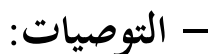

1. ت تنشيط التعايش السلمي في المجتمع، بالإثبات العلمي والعملي، لنبذ ما تمكن منه داعش، في بث

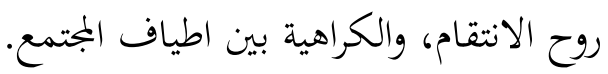

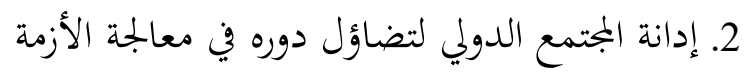
الراهنة، لا يكتفي الأمر بتتويج نادية مراد الناجية

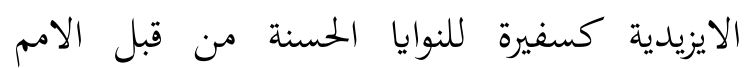

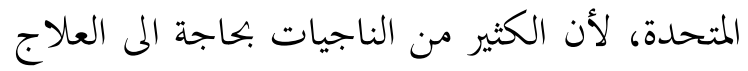

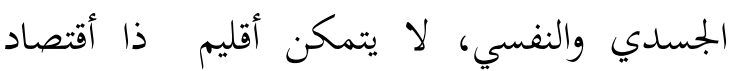
محدود تقديم الحذدمة المناسبة للمنكوبين.

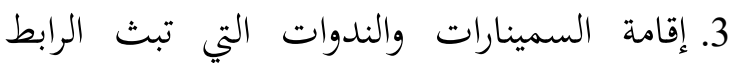

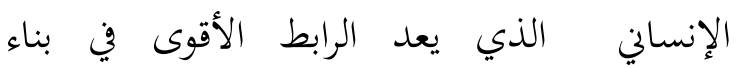

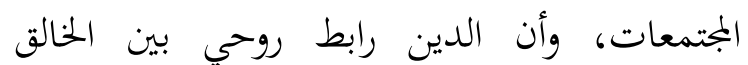

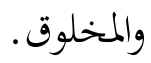

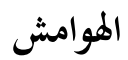

(1) حقوق الإنسان هي الحقوق والحريات الجمبع عليها والمعطاة

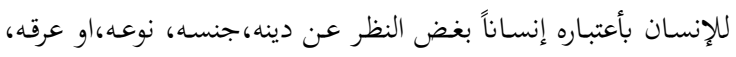

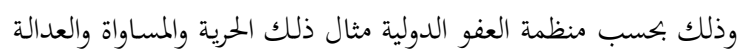

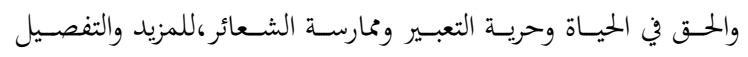

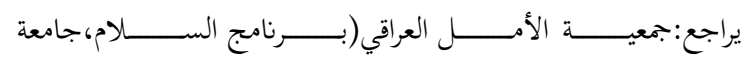

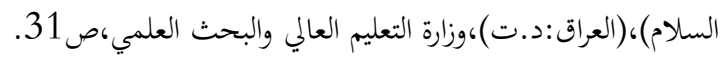

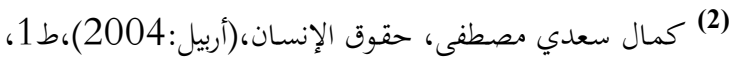

$$
\text { مكتب التنظيم بيشمه ركه، ص صن } 8 .
$$

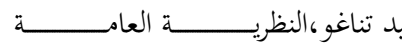

اللقانون،(الاسكندرية:1986)، ط1، دار المعارف، صن ص 130 -

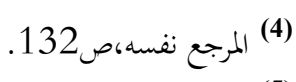

(5) عبـدالرهمن رحسيم، الـترابط العضـوي مـابين حقــوق الإنسـان

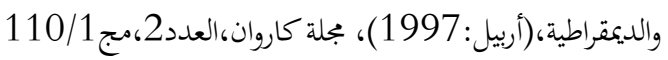

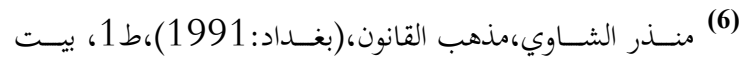

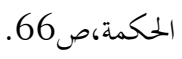

أساسية، منها مركز مدينة موصل، تحديداً في قاعة كلاكسي، وفي سوريا تحديداً في دير الزور، (مقداد: سعود: نافع) 11. تعدد جنسيات الدواعش بين العراقي، واعل والتونسي، والسوري وغيرهم، في استشهادات البحث. حيث وردت اسماء وجنسيات مختلفة على

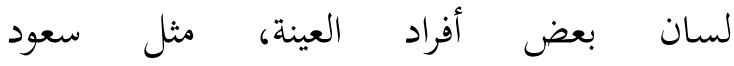
عراقي/موصل(حارس سجن بادوش)، ونافع سوري الجنسية يسجل اسماء النساء الجميلات بعد تحديدارهم بادوش) وناع سوري

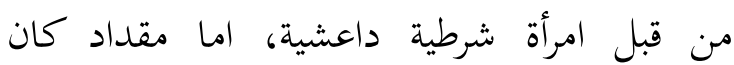
عراقي/تلعفر يمبر على الإسلام مقابل اللقاء بأولادهم الشباب ....... الخ. 12. في سلسلة عمليات الإنقاذ، صرفت الكثير من إن الاموال، ما لا يقل عن (10000دولار امريكي) مقابل الشخص الواحد، هنا بدأ الإتحار بهؤلاء

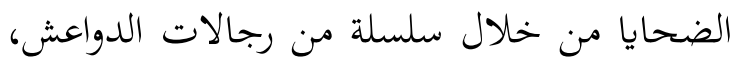
هنا سؤال يطرح نفسه، ما مقدار الاموال التي جناها داعش من هذه العملية؟ وكيف ستمولها؟ 13. لعب الحزب العمالي الكوردستانيpkkروراً

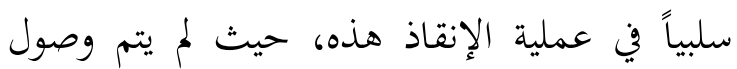

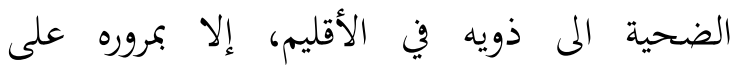
مراكزهم، وهذه الحقيقة تظهر في حالة هديل الحاملة في الشهر التاسع، عندما وصلت بين أيديهم، وأنجبت طفلها، هناك بسبب بعض الإعاقات، منعت من اصطحاها لابنها معها، واحتفظوا بالطفل، الذي يُجهل مصيره، بسبب عاطفة الأمومة قالت هديل: لو علمت بفصلنا عن البعض لفضلت العيش مع الإرهاب ولا أفقده. 
$-1564)$ ماش

:

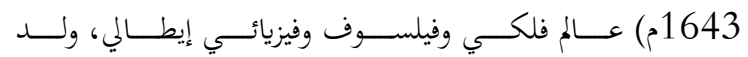

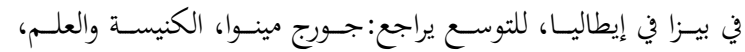

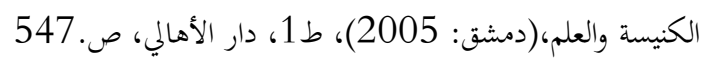

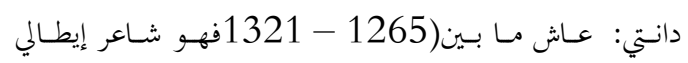

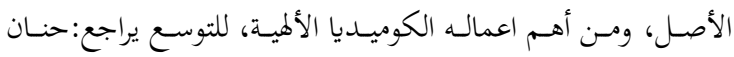

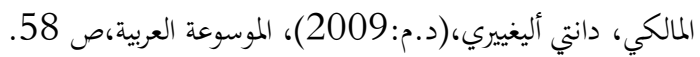
كوبر نيكوس:

راهب،وعالم رياضياتي وفيلسوف وفلكي وقانوني وطبيب وإداري ود؛

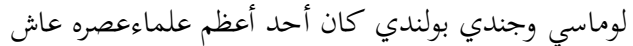

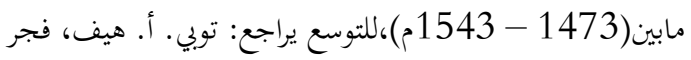

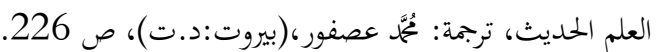

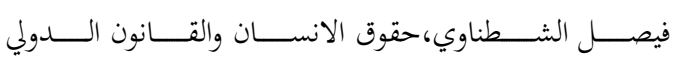
(20)

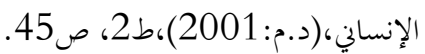

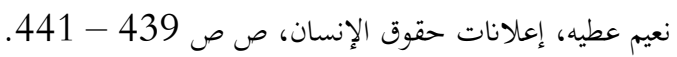
(21)

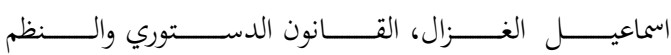
السياسية،(بيروت:1982)،ط 1، المؤسسة الجامعية، ص 48.

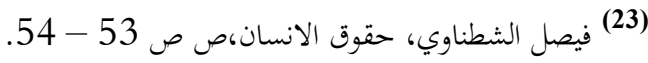
(24) كمال سعدي مصطفى، حقوق الإنسان، ص 9.

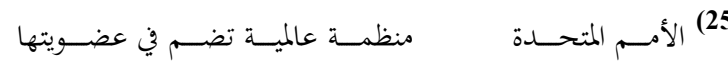

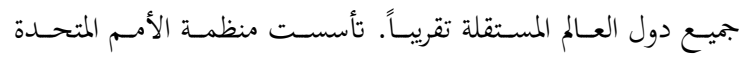

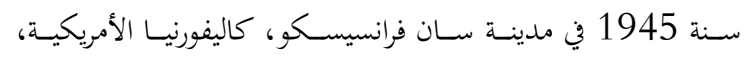
تبعاً لمؤتمر دومبارتون أوكس الذي عقد في العاصمة واشنطن ـيتم تمويل المنظمة من خلال المساهمات المقدرة والمساهمات الطوعية من الدول الأعضاء فيها. توجد مكاتب رئيسية أخرى في جنيف ونيروبي وفيينا،

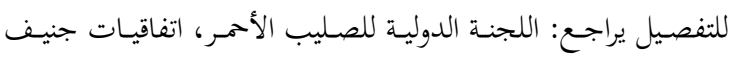
المؤرخة في 12 آب/أغسطس 1949،(د.م:2000 - 2009).

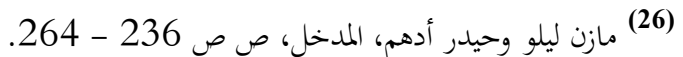

$$
\text { (28) المرجع نفسه. }
$$

(29) اتفاقية لاهـاي: هي عبارة عن معاهدتان دوليتان نوقشتا لأول

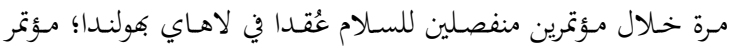

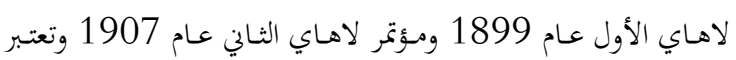

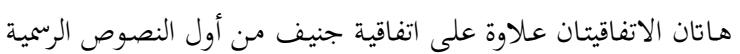

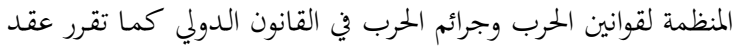

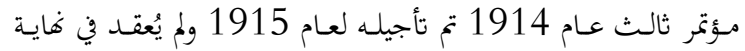

(7) كمال سعدي، حقوق الإنسان، ص 13.

$$
\begin{aligned}
& \text { (8) (لمرجع نفسه،ص14. }
\end{aligned}
$$

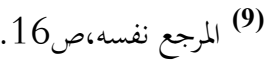

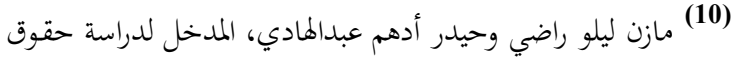

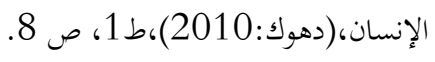

(11) قانون ممورابي: هي بجموعة قوانين بابلية يبلغ عددها 282 مادمادة 2010 مادة

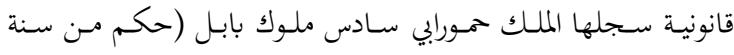

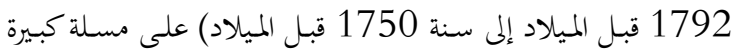

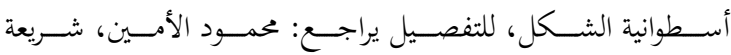
ممورابي،(بيروت:2003)،دار الفكر.

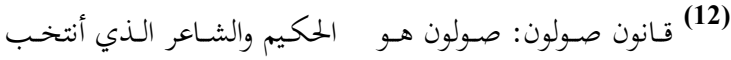

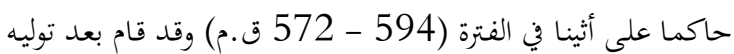
الحكم بوضع شرائع أو أحكام عرفت باسم قانون صولون أو شرائع

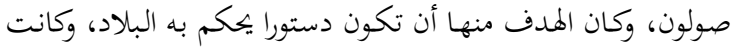
قوانيه متنوعة،لمزيد والتفصيل يراجع: ديورانت ول، قصة الحضارة،

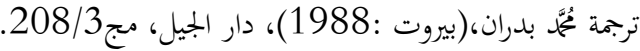

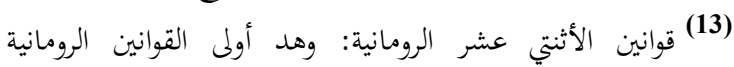

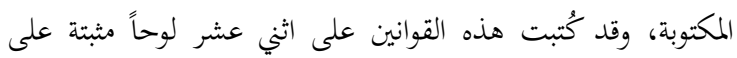

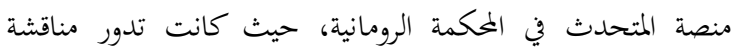
الأمور المهمة. وقد كانت هذه القوانين الأسس التي تقوم عليها

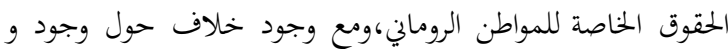

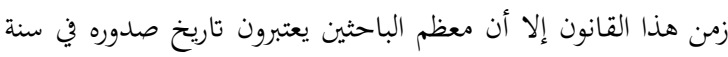

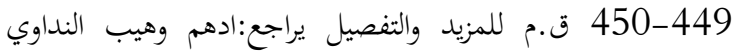

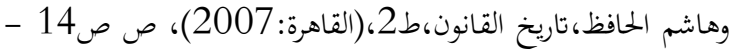

مُحَّمَ حسين سالمُ صقر وذياب بن مقبل الشراري، مبادئ حقوق

$$
\text { الإنسان،(عمان:2017)ط1 12، } 64 .
$$

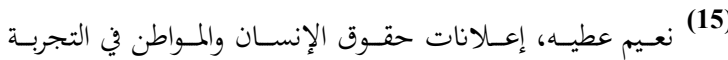
الدسـتورية الانكلوسكســـنية،(د.م:1973)، مجلــة إدارة قضــايا

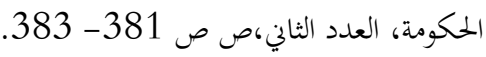

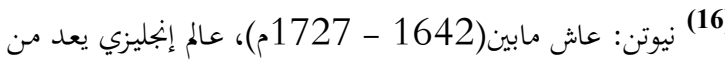

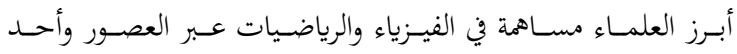

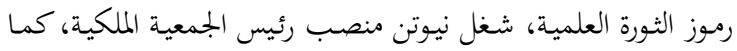

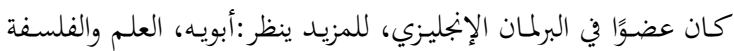

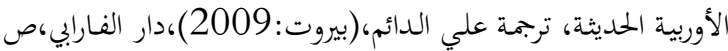


(51) اللجنة الدولية للصليب الأممر، اللحقان، ص 101.

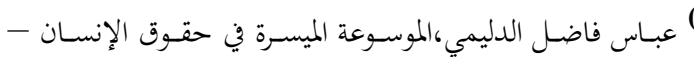

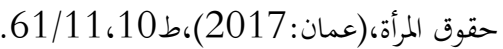

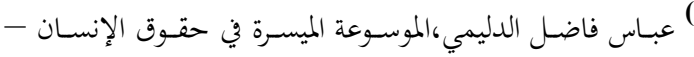

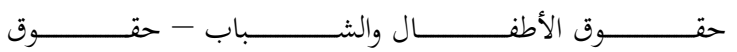

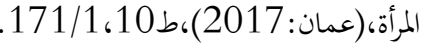
(54) عاصمة كينيا، عقد فيها بسنة1985 أجتماعات القمة المعنية بالمرأة. عقد في العاصمة الصينية بيكن(بيجن) المؤتمر العالمي الرابع في

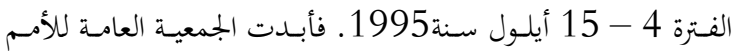

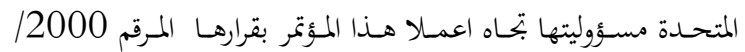

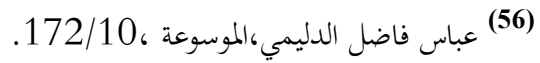

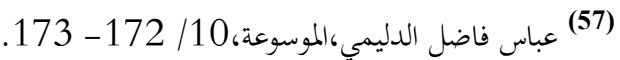

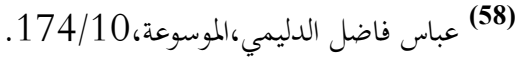

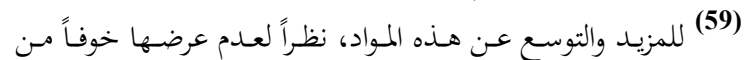

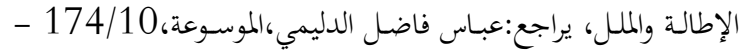

(60) عباس فاضل الدليمي،الموسوعة،182/10 183/10 - 196. (61) عباس فاضل الدليمي،الموسوعة، 197/10 - 225.

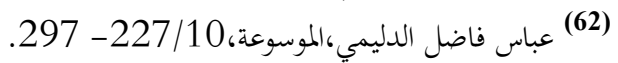

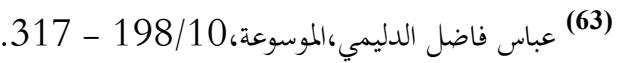

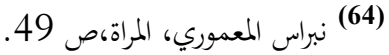

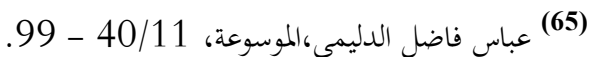
(66) نبراس المعموري، المرأة،ص صاسل 51 - 56 56؛ وللتوسع في موضوع

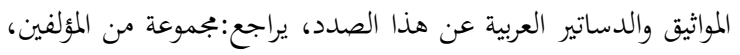
مأزق الدستور،(بغداد - بيروت:2006)،طانئ، معهد الدراسات

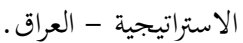

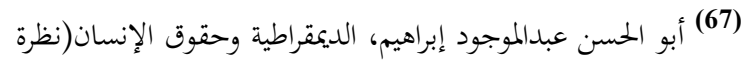

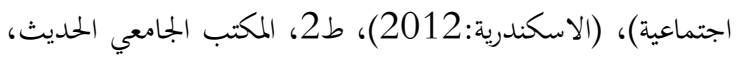

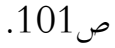
(68) (أمد عبده عوض، حقوق الإنسان بين الإسلام والغرب بين

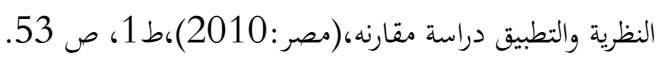

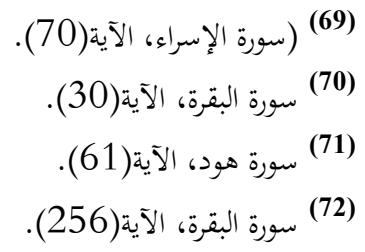

الأمر لنشوب، للمزيد والتفصيل يراجع: اللجنة الدولية ، اتفاقيات

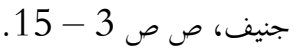

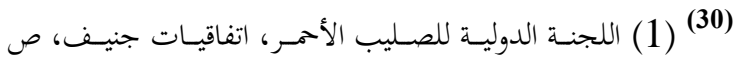
190

(31) (المرجع نفسه،ص4) (32) اللجنــة الدوليـة للصـليب الأمهـر، اللحقــان((البروتوكولان))

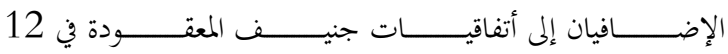

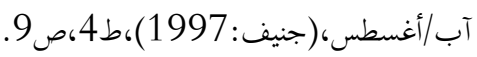

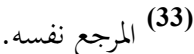
(34) (35) (35) المرجع نفسه. (35) (35) (35) المرجع نفسه. (36) المرجع نفسه.

(37) عبدالحسين شعبان،ثقافة حقوق الإنسان،(أربيل: 2001)،ط1، منشورات كاوا،،ص ص 12 - 13. (38) - (المرجع نفسه.

(39) أبو اليزيد علي المتيت، حقوق الإنسان الأساسية والديمقراطية - لمنس،

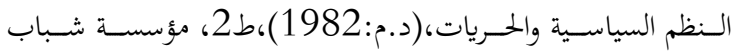
الجامعية، ص 160.

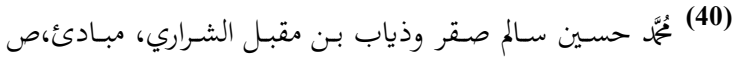

(41) للتوسع في موضوع العرق، يراجع: غوستاف لوبون، سيكولوجية

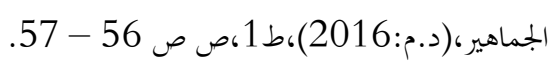
(43) المرجع نفسه.

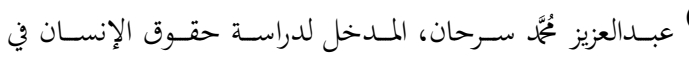
القانون الدولي،(د.م:1988)، ص 288 . 28

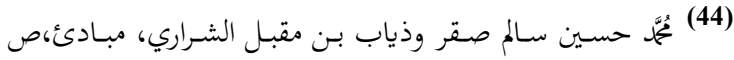

(45) مازن ليلو راضي وحيدر أدهم عبدالهادي، المدخل، 229.

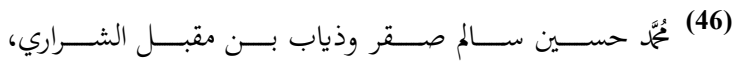

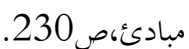

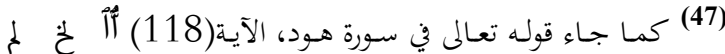

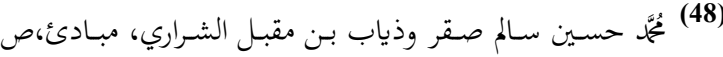

(49) نبراس المعموري، المرأة في الربيع العربي،(القـاهرة:2013)،ط1،

(50) اللجنة الدولية للصليب الأحمر، اللحقان، ص 61. 
1988)،ط13، 13/ 320، رقم الحديث( 2766)، باب الحديث (قبول

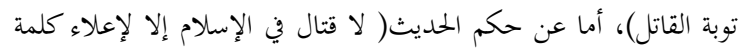

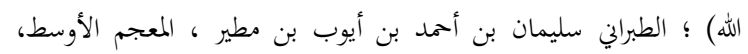

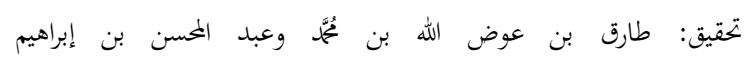

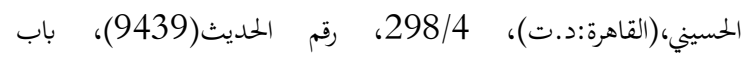

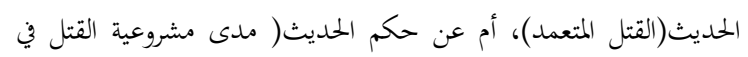
(الإسلام). (94) للتوسع بهـا الصـد يراجع:راغب السرجاني، أخـلاق،ص ص .156- 148

زيسـد بـن عبــالكريم، مقدمسـة في القـانون الــدولي الإنسـاني في

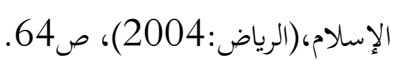$$
\text { (96) سورة التوبة، الآية(6). }
$$

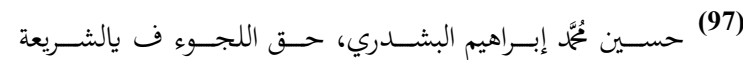

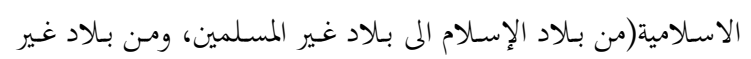

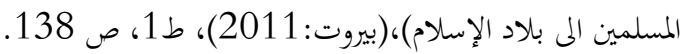

$$
\text { (99) سورة الكهف، الآية(29) }
$$

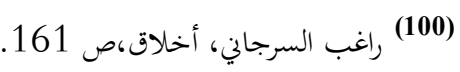
(101) (102) راغب السرجاني، أخلاق، الخدران، 161.

(102) راغب السرجاني، المشترك الإنساني نظرية جديدة للتقارب التهارب بين

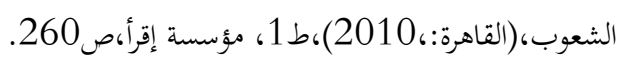

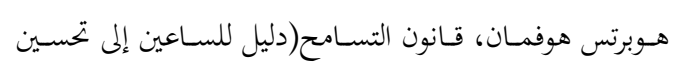

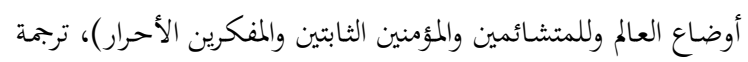

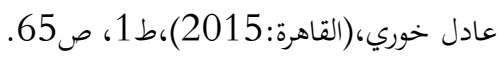
(104) أثوار أقط: الأثوار جمع ثور وهي القطعة من الشيء، والأقط:

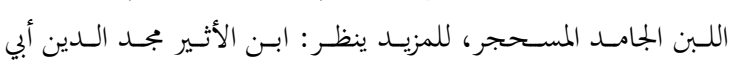

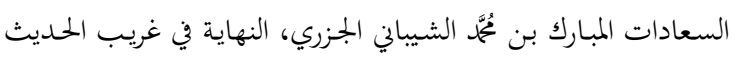

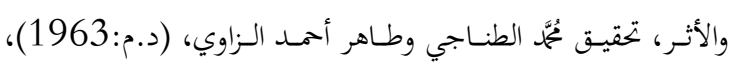

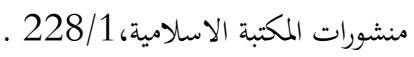

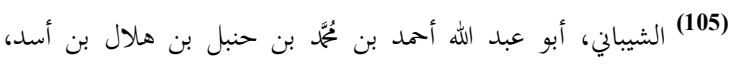

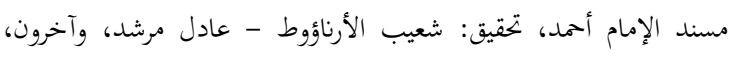

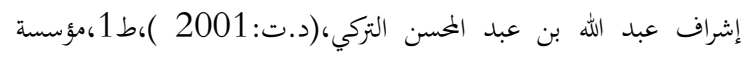

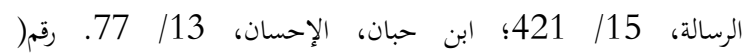

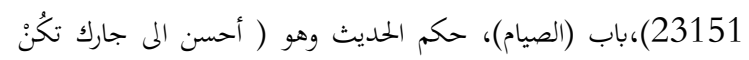

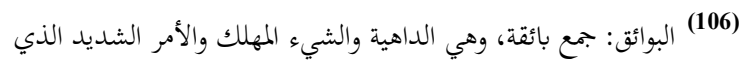

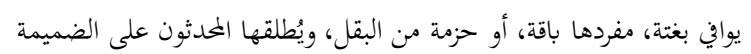

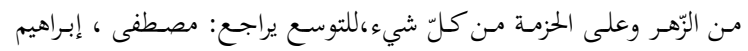

(73) سورة النساء، الآية(135)؛ سورة المائدة، الآية(8).

$$
\begin{aligned}
& \text { (74) سورة الإسراء، الآية(107). لإية(135). } \\
& \text { (75) سورة الكافرون، الآية(6). } \\
& \text { (76) سورة يونس، الآية(99). } \\
& \text { (77) سورة النحل، الآية(125). }
\end{aligned}
$$

(78) سورة المزمل، الآيـة(10)؛ للمزيد والتوسع عن الآيات القرآنيـة

التي تحث على عدم مقاتلة المخالفين للإسلام والحرية العقائدية ينظر :

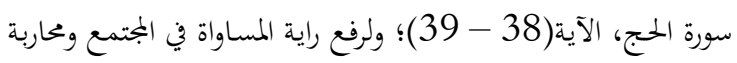

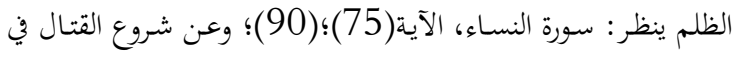

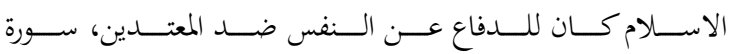

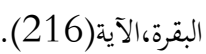

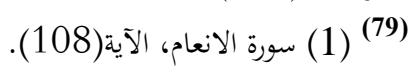

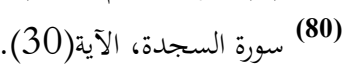

(81) سورة الحج، الآية(40).

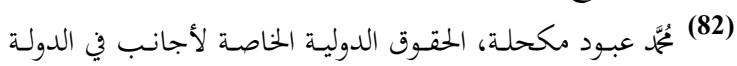

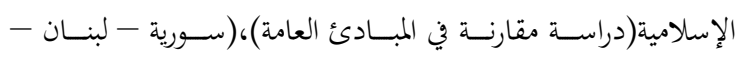

$$
\text { الكويت:2012)، 183، ص } 249 .
$$

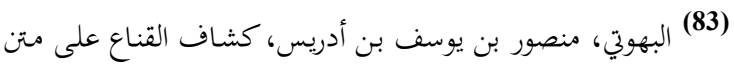

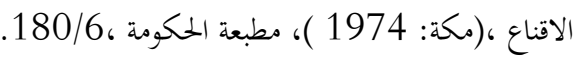

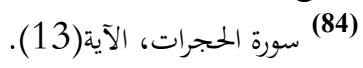

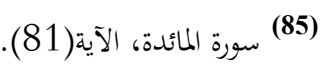

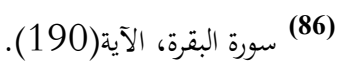

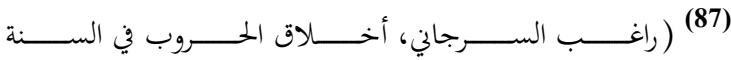

النبوية،(القاهرة:2010)،ط 1ابص 137.

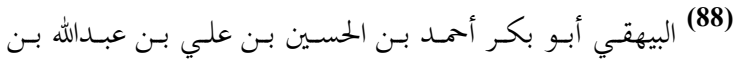

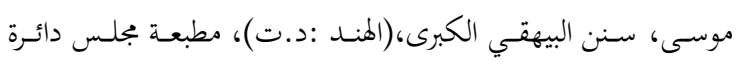

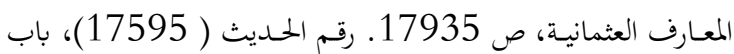

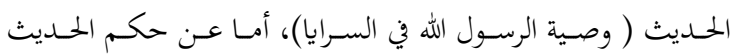

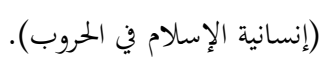

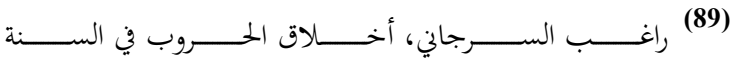

النبوية،(القاهرة: 2010)،ط 1،ص 137.

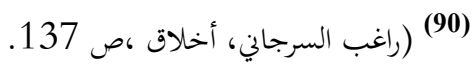

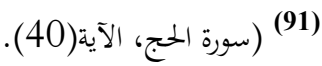

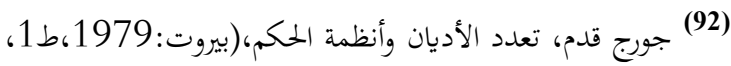

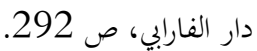

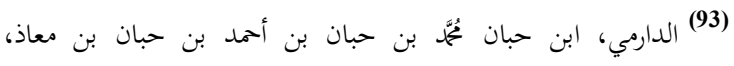

الإحسان في تقريب صحيح ابن حبان، مؤسسة الرسالة، (بيروت: 
الإسـلامي والقضـايا المعاصرة،(دمشـق:2012)، ط3، دار الفكـر، $602-601 / 13$

$$
\text { 118 المرجع نفسه،604/13. }
$$$$
\text { سورة النور، الاية(2). }
$$

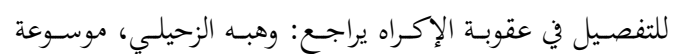

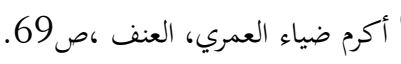

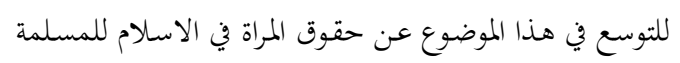

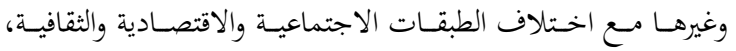

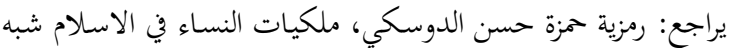

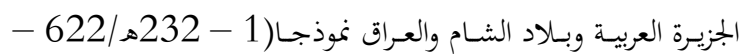
846م)،(الموصل:2015)، اطروحة دكتوراه غير منشورة.

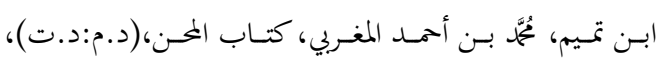
ص317. كما يشكك في سند هذا القول للفاروق.

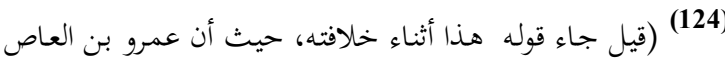

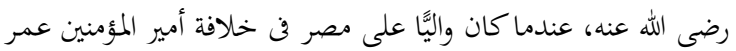

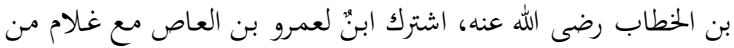

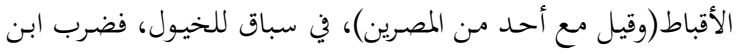

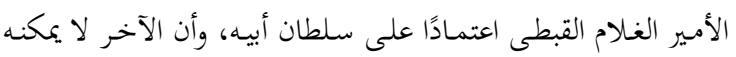

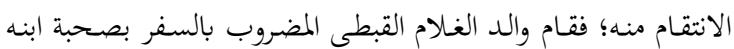

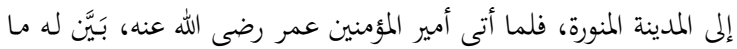

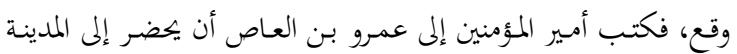

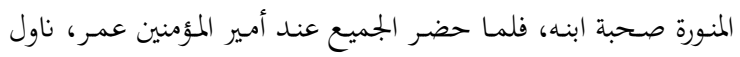

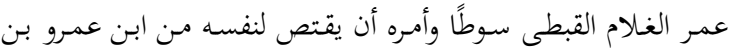

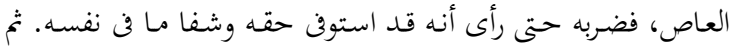

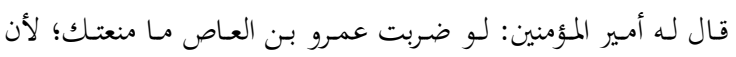
الغلام إنما ضربك لسطان أبيه، ثم التفت إلى عمرو بن العاص قائلاً:

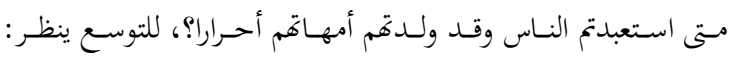

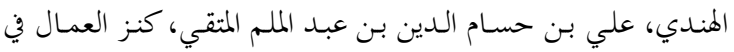

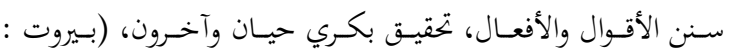
1979)، مؤسسة الرسالة، 1960/12.

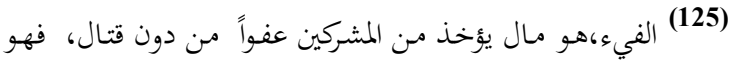

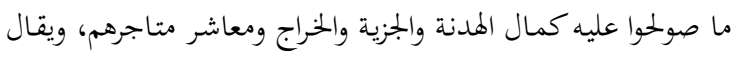

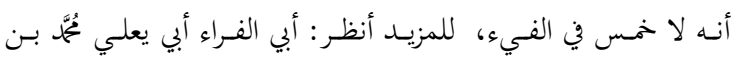

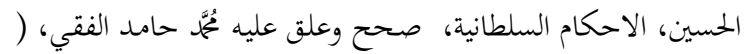

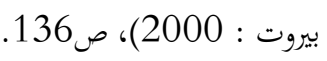

وأحمد حسن الزيات وحامد عبد القادر ولمُحَّ علي النجار، المعجم الوسيط

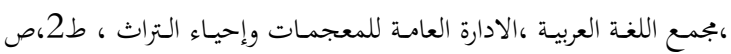

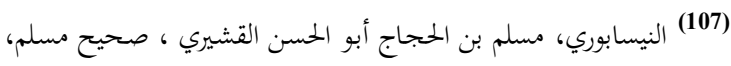

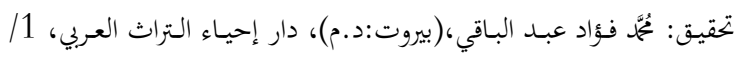

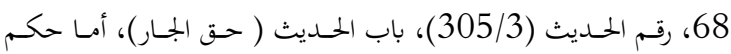

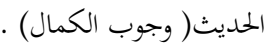

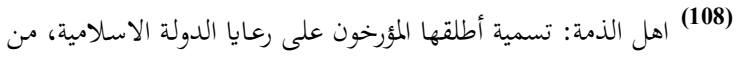

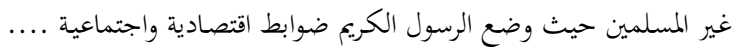

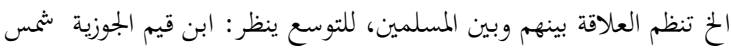

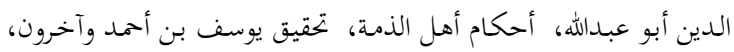

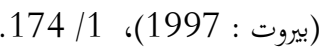
(109) المعاهد: أكثر مـا يطلق على أهل الذمة ، للتوسع ينظر الى:

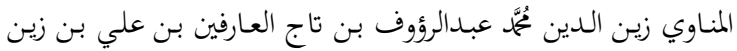

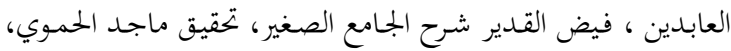

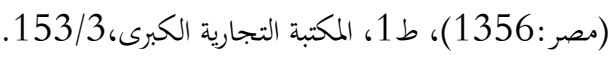

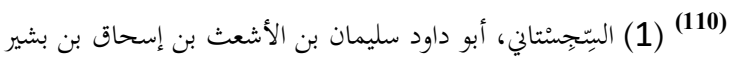

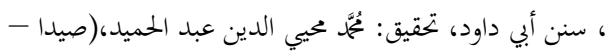

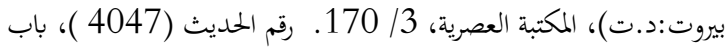

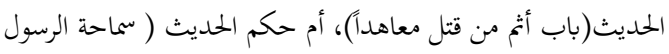

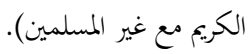
(111) سمورة آل عمران، الآية(104).

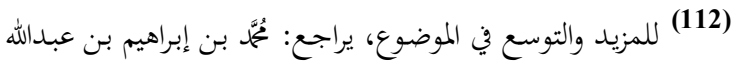

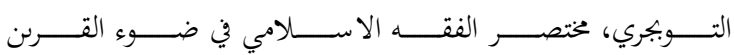

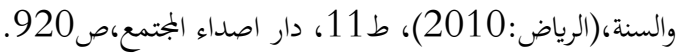

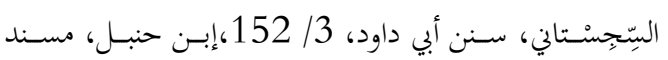

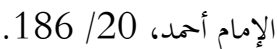

(114) للتوسع في هذا الموضوع عن حقوق المراة في الاسلام للمسلمة

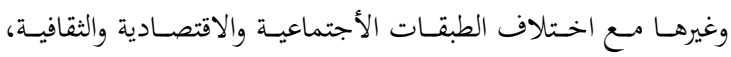
يراجع: رمزية حمزة حسن الدوسكي، ملكيات النساء في الاسلام شبه ولهابه

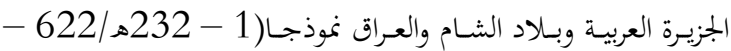
846م)،(الموصل:2015)، اطروحة دكتوراه غير منشورة.

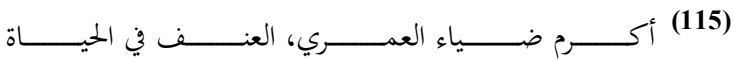
الزوجية،(الرياض:2008)،ط 116،صريط 7.

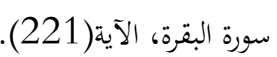

(117) للتوسع في رآي الإسلام عن إبطال هذا الزواج، وعـده ضمن الزية قائمـة الزنا والزواج الفاسـد، يراجـع: وهبـة الزحيلي، موسـوعة الفقـهـ 
العسقلاني شهاب الدين ابو الفضل احمد بن علي بن حجر،

فتح الباري،(بيروت:1959)، دار المعرفة ، 113/5.

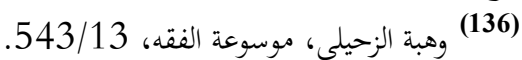

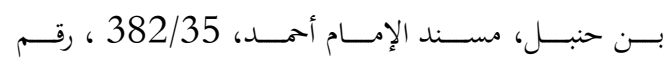

الحمديث( الحيث)

$$
\text { الحديث( النصحية في الدين الاسلامي). }
$$

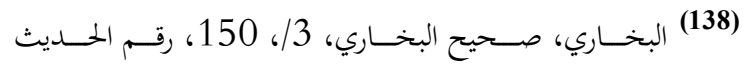

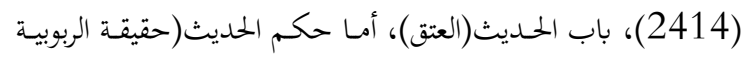

(لله تعالى). (133)

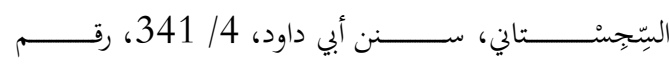

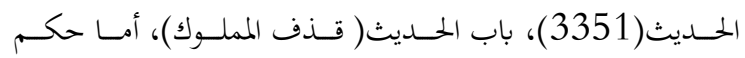

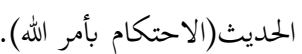

سورة النساء، الآية(36).

(140)

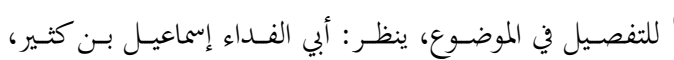

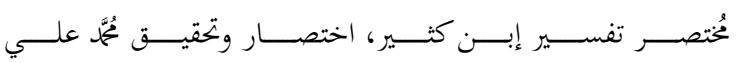

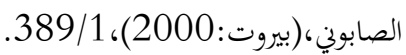
(142)

(143) مركز الناجيات الايزديات: يعتبر من أحدى وأهم فرق الانقاذ

التي تبناها رئيس حكومة إقليم كوردستان السيد(نيجرفان البارزاني) في

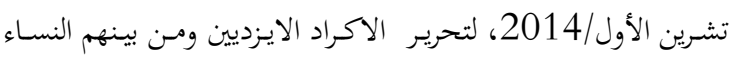

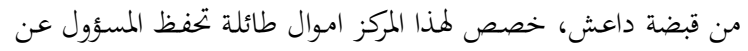

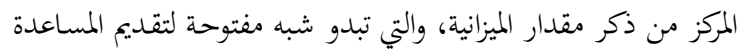

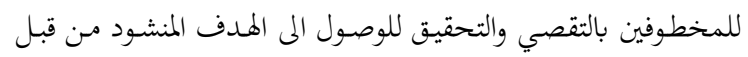

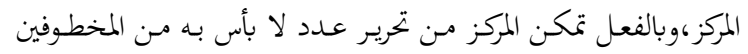

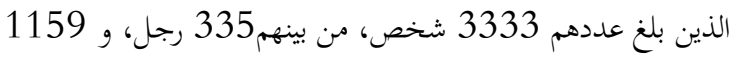

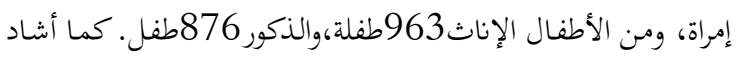

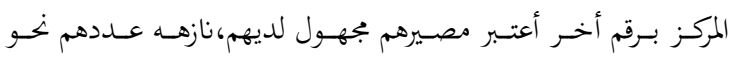

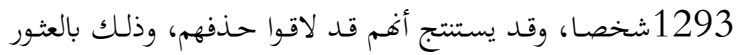

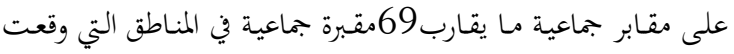

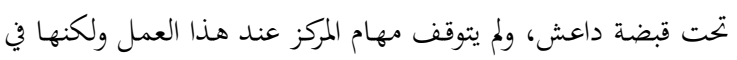

نشاط دائم لتحرير من نبقى من ذويهم بقبضة داعش الإرهابي.

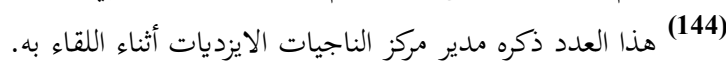

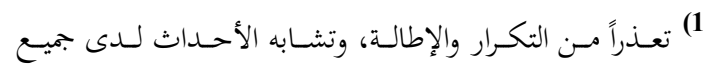

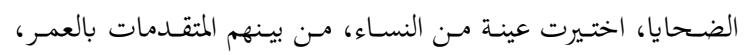
والمتوسطات، والشابات..

أثناء اللقاء الذي أجري مع ( حسبين القائدي) رئيس مركز (146)

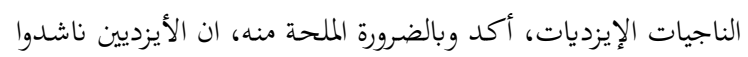

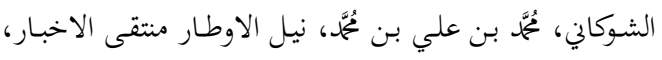

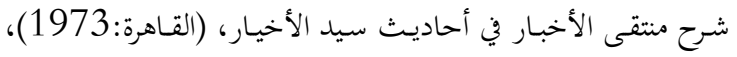
دار الجيل،236/8.

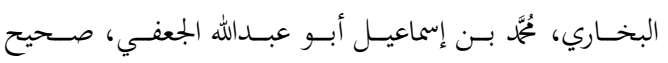

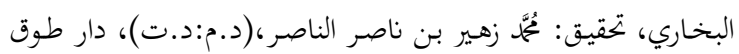

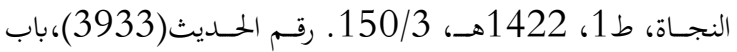
الحديث(العتق)، أما حكم الحديث( رفع الزيادتين في الأجر عند الله).

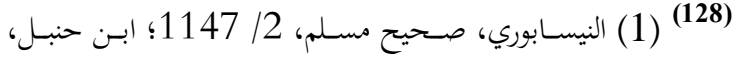

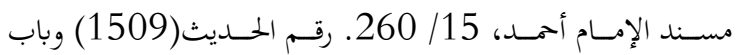

الحديث(باب فضل العتق)، أما حكم الحديث(استحباب العتق).

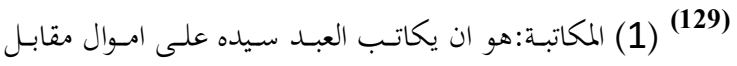

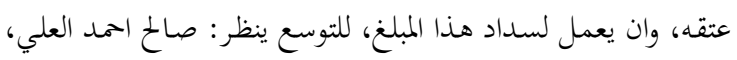

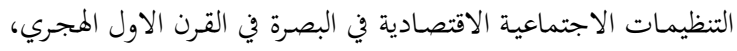

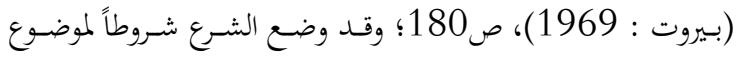

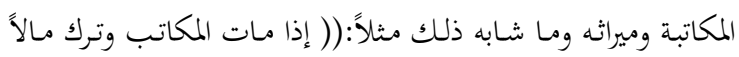

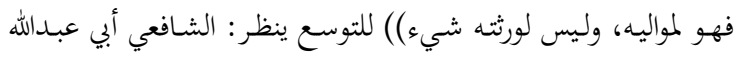

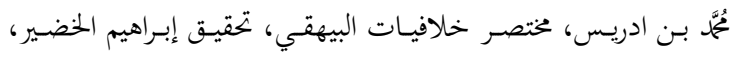

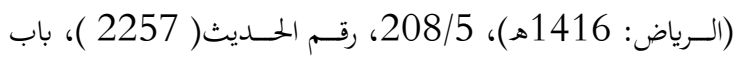

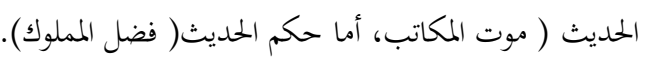

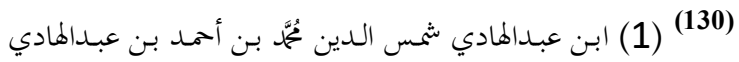

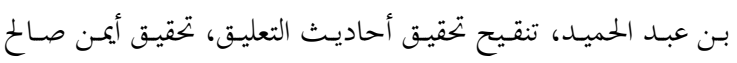
شعبان، (بيروت:1998)، 563/3. الـذهبي الحسافظ شمس الـدين، تاريـخ الاسلام(السيرة النبويـة) حوادث وفيات 61 - 80، تحقيق عبدالسلام تدمري، (بيروت :

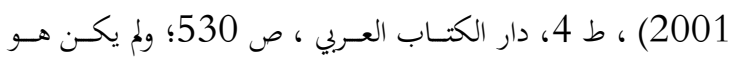

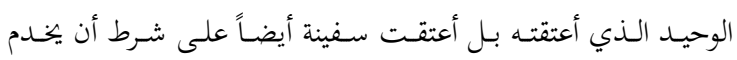

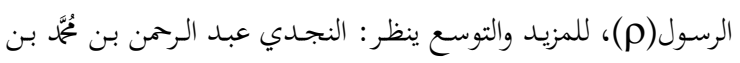

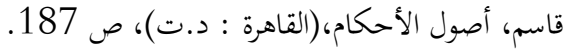
(132) (13) الصفدي صلاح الدين خليل بن إيبك، الوافي بالوفيات،

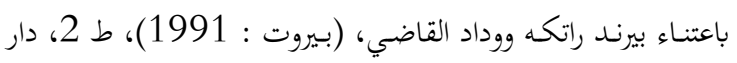

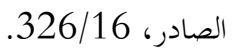

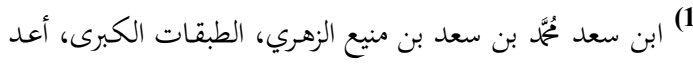
(133)

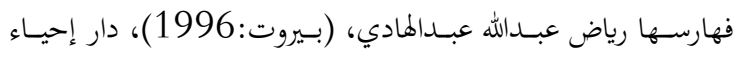

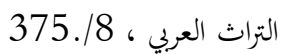

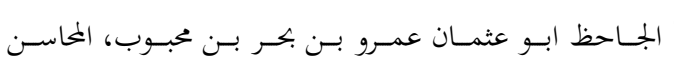
(134)

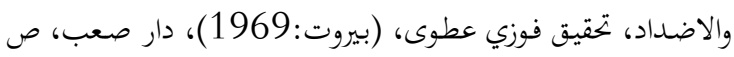




$$
\begin{aligned}
& \text { (148) تاريخ الشعي الكردي حافل بجرائم الإبادة بالكيمياوي بحقهم، } \\
& \text { مابين القتل الجماعي والإنفال وماشابه ذلك. } \\
& \text { (149) أتضحت هذذه الصورة في عمليـات الإنقاذ التي ذكرتما والدةد } \\
& \text { هيثم، وهديل، وغيرهم. } \\
& \text { (150) اول خطوة بعد عمليـات الإنقاذ يقوم مركز الناجيات، بملئ }
\end{aligned}
$$

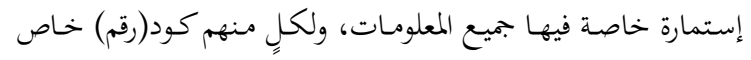

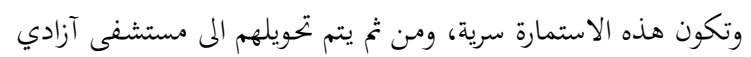

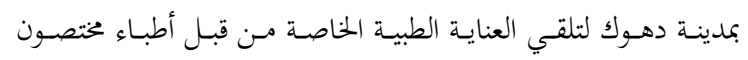

$$
\begin{aligned}
& \text { أمثال(د.ملى و د. نغم) }
\end{aligned}
$$

$$
\begin{aligned}
& \text { الحكومة العراقية، وفي لقاء شخصي مع سيلم الجبوري رئيس برلمان }
\end{aligned}
$$

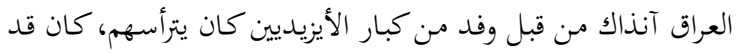

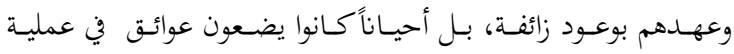

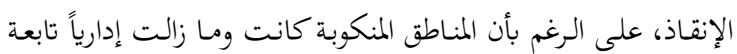

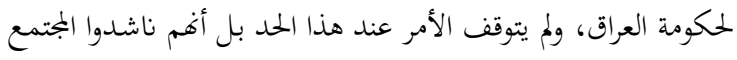

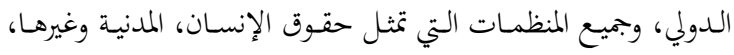

$$
\begin{aligned}
& \text { فضلاً عن الدولة الاسلامية. } \\
& \text { (1477) هذه الصلاة قد تكون انتقاميه، لأنه من السنة النبوية المؤكدة في }
\end{aligned}
$$

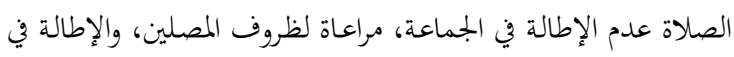

$$
\begin{aligned}
& \text { حالة الانفراد كيف يشاء الفرد، وذلك لملازمة السماحة والاعتدال في } \\
& \text { التكليف، للتوسع يراجع:وهبه، موسوعة الفقه، 644/13 - } 645 \text { التراد }
\end{aligned}
$$

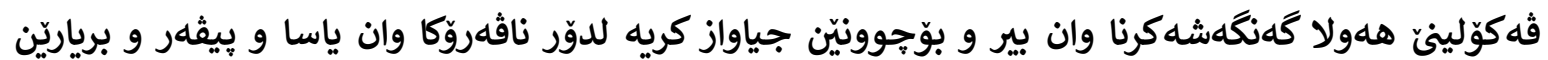

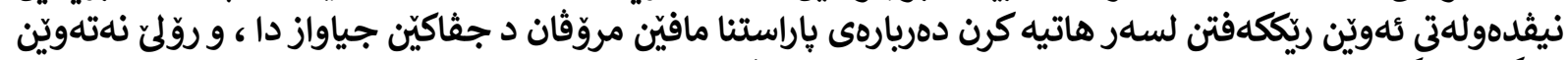

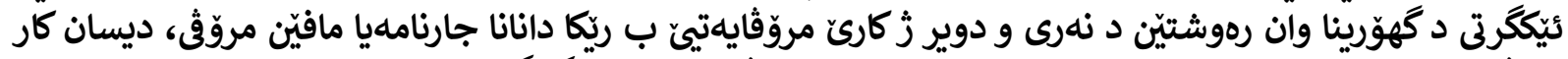

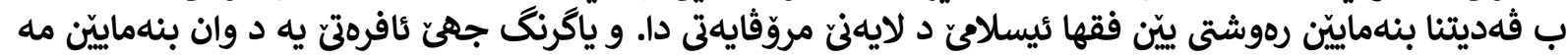

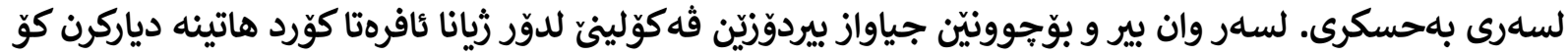

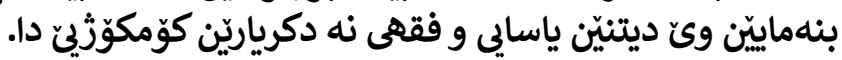

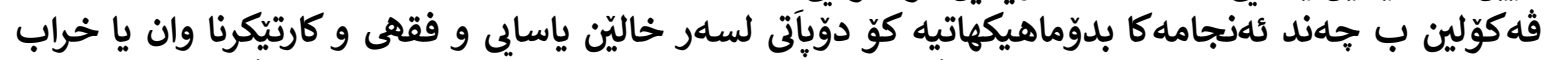

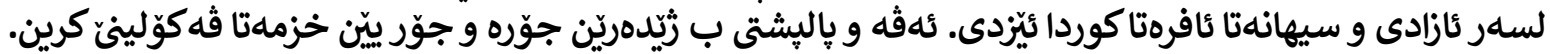

\section{KURDISH YAZIDIAN'S WOMEN IN LEGAL AND JURISPRUDENCE REFLECTIONS "ISIS CRIMES" \\ RAMZIYA HAMZA}

Dept. of Religion Educations, College of Humanities Studies, University of Duhok, Kurdistan Region- Iraq

\section{ABSTRACT}

This study aims to discuss the problematic aspects of the international systems and decisions, the agreed standards for the protection of human rights in different societies, and the effective role of the united nations in changing the anomalous behavior through its development of the hluman Rights charter.

This study also sheds light or the ethical principles of Islamic jurisprudence in dealing with the humanity aspects. The interesting thing here to humanity aspects. The to know is position of the woman,and form this probamatic aspect, the hyposes of the study has been derived from the practical aspect in the legal and juris prudence implications of the genocide crimes.

This study coucluds with several results which indicate legal and jurisprudence mutations that are reflected negatively form depriving the freedom and the dignity of the Kurdish Yazidis woman .This study takes all the aspecds of. The topic into consideration by conducting many different resources.

KEYWORDS: Women, International Laws, Genocide, Human Rights, Islam 